\title{
Challenges Faced with Small Molecular Modulators of Potassium Current Channel Isoform Kv1.5
}

\author{
Zefeng Zhao ${ }^{1,2}$, Songsong Ruan ${ }^{1,2}$, Xiaoming Ma ${ }^{1,2}$, Qian Feng ${ }^{1,2}$, Zhuosong Xie ${ }^{1,2}$, \\ Zhuang Nie ${ }^{1,2}$, Peinan Fan ${ }^{1,2}$, Mingcheng Qian ${ }^{3,4}$, Xirui He ${ }^{5}$, Shaoping $\mathrm{Wu}^{1,2, * \mathbb{D}}$, \\ Yongmin Zhang ${ }^{1,2,6}$ (D) and Xiaohui Zheng ${ }^{1,2}$
}

1 Key Laboratory of Resource Biology and Biotechnology in Western China, Ministry of Education, Northwest University, 229 Taibai Road, Xi'an 710069, China; zzf598155752@sina.com (Z.Z.); ruansongsong@stumail.nwu.edu.cn (S.R.); 201720920@stumail.nwu.edu.cn (X.M.); fengqian@stumail.nwu.edu.cn (Q.F.); 18821657783@163.com (Z.X.); nz19980217@163.com (Z.N.); f568902@163.com (P.F.); yongmin.zhang@upmc.fr (Y.Z.); zhengxh@nwu.edu.cn (X.Z.)

2 Biomedicine Key Laboratory of Shaanxi Province, School of Pharmacy, Northwest University, 229 Taibai Road, Xi'an 710069, China

3 Department of Medicinal Chemistry, School of Pharmaceutical Engineering and Life Science, Changzhou University, Changzhou 213164, China; mqian2019@cczu.edu.cn

4 Laboratory for Medicinal Chemistry, Ghent University, Ottergemsesteenweg 460, B-9000 Ghent, Belgium

5 Department of Bioengineering, Zhuhai Campus of Zunyi Medical University, Zhuhai 519041, China; xiruihe@163.com

6 Sorbonne Université, Institut Parisien de Chimie Moléculaire, CNRS UMR 8232, 4 place Jussieu, 75005 Paris, France

* Correspondence: wushaoping@nwu.edu.cn; Tel.: +86-029-88304569

Received: 13 November 2019; Accepted: 10 December 2019; Published: 19 December 2019

\begin{abstract}
The voltage-gated potassium channel Kv1.5, which mediates the cardiac ultra-rapid delayed-rectifier $\left(I_{\text {Kur }}\right)$ current in human cells, has a crucial role in atrial fibrillation. Therefore, the design of selective Kv1.5 modulators is essential for the treatment of pathophysiological conditions involving Kv1.5 activity. This review summarizes the progress of molecular structures and the functionality of different types of Kv1.5 modulators, with a focus on clinical cardiovascular drugs and a number of active natural products, through a summarization of 96 compounds currently widely used. Furthermore, we also discuss the contributions of Kv1.5 and the regulation of the structure-activity relationship (SAR) of synthetic Kv1.5 inhibitors in human pathophysiology. SAR analysis is regarded as a useful strategy in structural elucidation, as it relates to the characteristics that improve compounds targeting Kv1.5. Herein, we present previous studies regarding the structural, pharmacological, and SAR information of the Kv1.5 modulator, through which we can assist in identifying and designing potent and specific Kv1.5 inhibitors in the treatment of diseases involving Kv1.5 activity.
\end{abstract}

Keywords: potassium channel; Kv1.5; KCNA5; modulators; SAR

\section{Introduction}

The voltage-gated potassium channel Kv1.5, which mediates the cardiac ultra-rapid delayed-rectifier $\left(I_{\mathrm{Kur}}\right)$ current in cells [1], is an attractive familial atrial fibrillation (AF) type 7 drug target, because it is selectively expressed in the atria but not in the ventricles of human cells [2]. AF is the most common cardiac arrhythmia facing physicians, afflicting $13 \%$ of men and $11 \%$ of women over 85 years of age. In atrial tissue from AF donors, the inhibition of $I_{\text {Kur }}$ extends the repolarization phase of the atrial cardiac action potential, thereby providing desirable antiarrhythmic effects without the risk of drug-induced 
torsade de pointes. It is noteworthy that loss-of-function $\mathrm{Kv} 1.5$ mutations are associated with $\mathrm{AF}$, and many companies are currently exploring $I_{\mathrm{Kur}}$ modulators for the treatment of $\mathrm{AF}$ [3].

The Kv1.5 protein is encoded by the KCNA5 gene with a length of 602 amino acids in mice (Unitprot Entry: Q61762) and rat (Unitprot Entry: P19024) sequences and 613 amino acids in the human sequence (Unitprot Entry: P22460). According to the Basic Local Alignment Search Tool (BLAST) result, the sequence of Kv1.5 is similar to homology targets Kv1.1, Kv1.2, and Kv1.3 in most regions, whereas differences mainly occur toward the start and end terminals of the sequence (see Figure 1C,D). The Kv1.5 channel belongs to the shaker-type voltage-gated $\mathrm{K}^{+}$channel family, and it comprises four pore-forming $\alpha$-subunits, each containing six transmembrane segments, named S1-S6 [4,5]. A pore region is formed between the pore helix and S6 domain of each subunit, which contains the selectivity filter through which $\mathrm{K}^{+}$ions flow across the plasma membrane [6,7]. Currently, the structure of the Kv1.5 protein is still awaiting identification; however, alanine-scanning mutagenesis and homologous modeling studies provide us with some amino acids, including Thr479, Ile502, Val505, Ile508, and Val512, which reside within the deep pore (Thr479-Val481) and lower S6 (Cys500-Val512) regions as putative binding sites for open-channel blockers [8-13] (Figure 1B). This not only helps us to understand the drug targets more comprehensively, but also saves time with regard to the development of potential clinical candidates in the future. From this perspective, we highlight recent advances in the discovery of small molecules as modulators of Kv1.5, and we discuss the structure-activity relationship (SAR) studies of currently used synthetic Kv1.5 inhibitors.

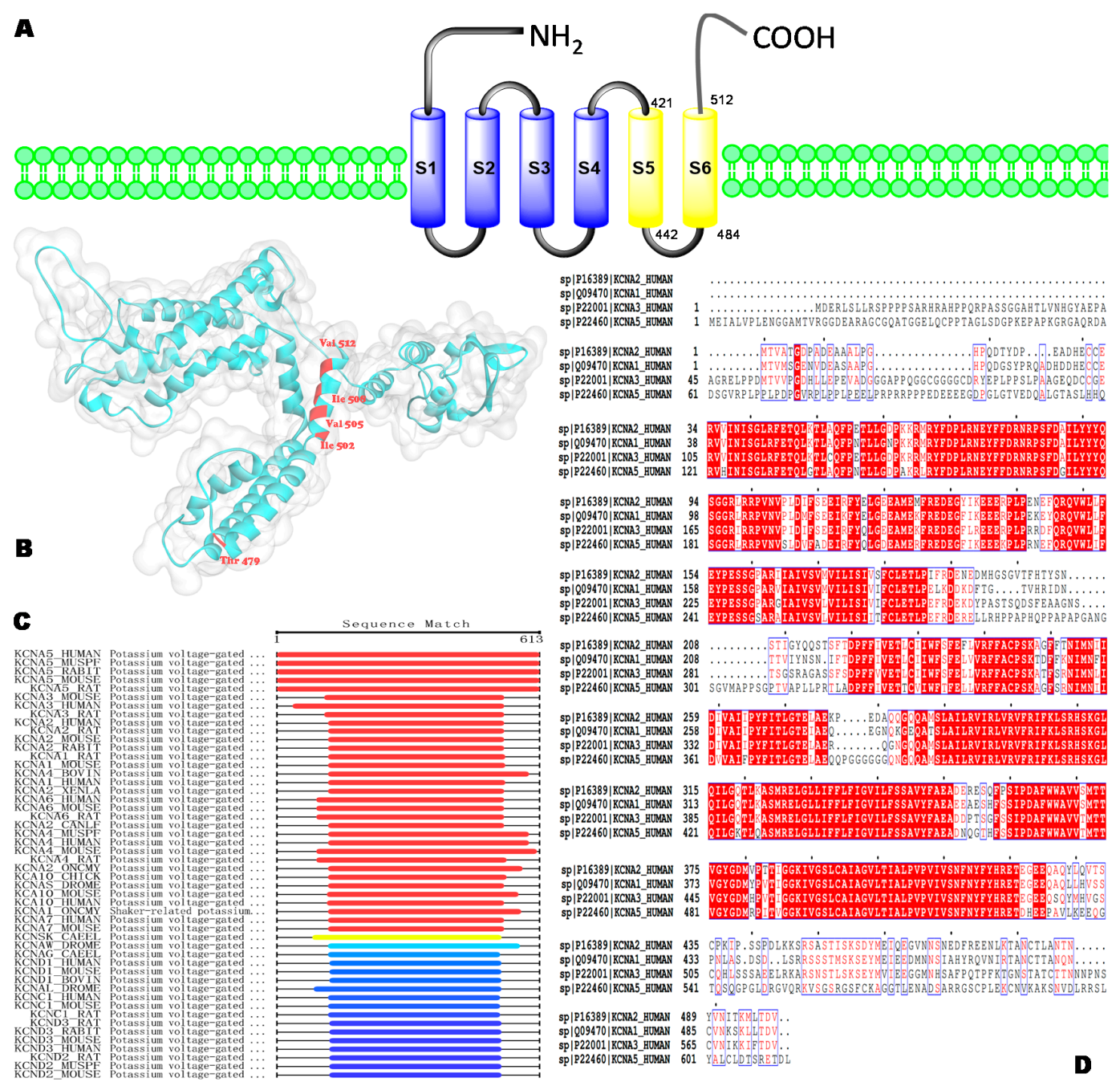

Figure 1. (A) Schematic representation of the $h \mathrm{Kv} 1.5 \alpha$-subunit with the sequence of the S6 region 
listed. (B) Homologous model of Kv1.5 (Q61672) with 67.2\% similarity for the Kv1.5 sequence, obtained from the SWISS-MODEL database; some of the residues are slightly different from those published in previous research. (C) Basic Local Alignment Search Tool (BLAST) result of KCNA5_HUMAN (P22460), obtained from the NCBI BLAST+ database. (D) Sequence alignment ofKCNA1_HUMAN (Q09470), KCNA3_HUMAN (P22001), KCNA2_HUMAN (P16389), and KCNA5_HUMAN (P22460), acquired from the ESPript database.

\section{Summarization of Models and Mechanisms of Kv1.5 Modulators}

To date, various kinds of Kv1.5 modulators have been disclosed, herein, we summarize the molecular structures and functionality of different types of Kv1.5 modulators with their chemical structure as follows (Table 1, Figure 2). As shown in Table 1, the existing Kv1.5 modulators can be divided into four categories: clinical cardiovascular drugs (1-14), other clinical drugs (15-28), drugs in development (29-37), and natural products (38-56). With the development of pharmacology, more and more experiment models including rats, HEK cells, $\mathrm{CHO}$ cells, Xenopus laevis oocytes, and Ltk ${ }^{-}$ cells have been used to evaluate the effect of Kv1.5 channel modulators; the parameters containing mRNA expression, $I_{\text {Kur, }}$ effective refractory period (ERP), and action potential duration (APD) were utilized to reveal the improvement degree of AF. In principle, the Kv1.5 modulators can lengthen the time course of ERP and APD to protect heart from the harm of AF.

Although the structure of Kv1.5 protein has not been characterized yet, current researches provide information for the development of Kv1.5 inhibitors according to fragment-based drug design and structure-based drug design. In regard to the design of Kv1.5 inhibitor, for the instance of the typical candidate vernakalant, in the pharmacophore model, hydrogen bond receptor, hydrogen bond donor, and hydrophobic groups should be present in the structure (Figure 2A) to play a role in the transmembrane effect to interact with the Kv1.5 channel. From the potential binding domain of vernakalant in Kv1.5 [8,14] (Figure 2B), we can see that the positively charged moiety bound in the cationophilic inner pore (mainly formed by electron-donating residues including alanine, leucine, and valine) formed a cationic "blocking particle" causing a block of the potassium channel; additionally, the uncharged dimethoxyphenyl moiety of a vernakalant has a tendency to bind in hydrophobic subunit interfaces including residues Ile 502 and Val 505. Functionally important residue isoleucine I502 in the inner helix S6 is exposed into the subunit interface of the pore module rather than into the inner pore. It is worth noting that mutations of Ile 502 decrease the potency of vernakalant, flecainide, and AVE0118, which are the ligands with a long hydrophobic tail in the side chain of the structure.

It seems that the introduction of heterocyclic rings including pyrrole (vernakalant, bepridil, clemizole, and BMS-394136) and piperdine (lobeline, CD-160130, bupivacaine, paroxetine, and donepezil) is important because these moieties usually influence the acidification conditions of the molecules, in which a potentially protonated and thus positively charged drug may enter deeply into the channel pore in a voltage-dependent way [15].
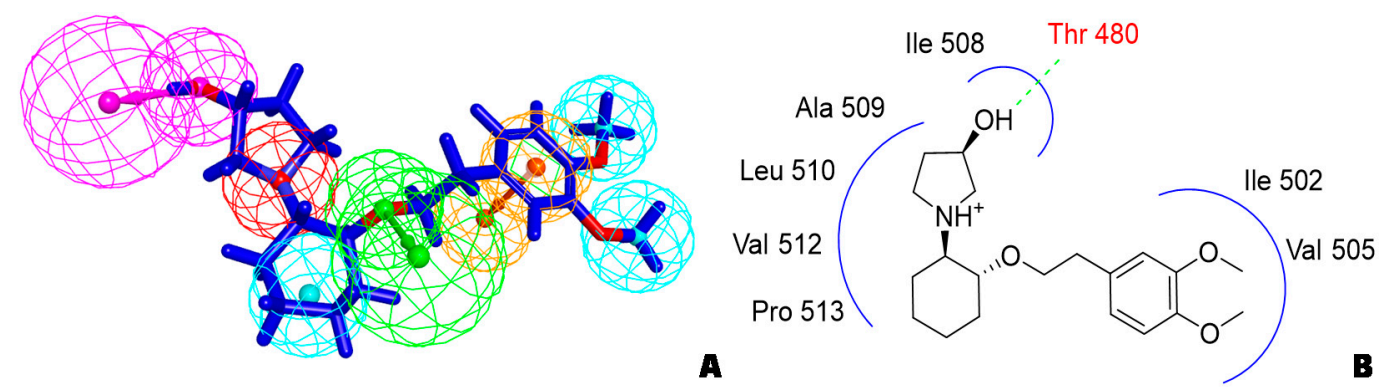

Figure 2. (A) Pharmacophore model of vernakalant (cyan ball: hydrophobic center; yellow ball: aromatic center; green ball: hydrogen bond receptor; pink ball: hydrogen bond donor; red ball: ionizable positive center); (B) potential binding domain of vernakalant in Kv1.5 (H-bond is expressed as green dashed). 
As a result of the definite curative effects and pharmacokinetic parameters proved by clinical trials, conventional drugs in new use trends seem to be a feasible way to develop new therapy. Multiple cardiovascular drugs not designed for targeting Kv1.5 have shown Kv1.5 inhibitory effect including quinidine (9) and diltiazem (10), however, the selectivity of these compounds on Kv1.5 still needs to be investigated.

As for other clinical drugs, CNS agents include: donepezil (15), which is generally used as an anti-Alzheimer's agent; paroxetine (16), fluoxetine (17), and sertraline (18), which are usually used as antidepressant agents; and bupivacaine (23), propofol (24), midazolam (25), tolbutamide (26), and benzocaine (27), which are utilized as anesthetic agents. $h$ ERGs (human ether-à-go-go-related genes) are widely associated with CNS diseases [16-18], thus it is not strange that active CNS agents can effectively modulate Kv1.5 according to the homology of the protein. Especially the neurotransmitter acetylcholine, which is an important substance that modulates the acetylcholine-activated $\mathrm{K}^{+}$current [19], however, only the piperidine type acetylcholine inhibitor donepezil showed significant inhibitory effect on Kv1.5, the same phenomenon was not present in another inhibitor tacrine [15], suggesting the selectivity of the binding site of Kv1.5.

Generally, Kv1.5 drugs in development are not going smoothly. The projects listed in Table 1 have been discontinued till now. Effectiveness, toxicity, and druggability should be taken into account at this stage. Persistence of investigation in this field is necessary because the listed compound like AZD-7009 (30) can not only alleviate the suffering of patients from intermittent AF but also

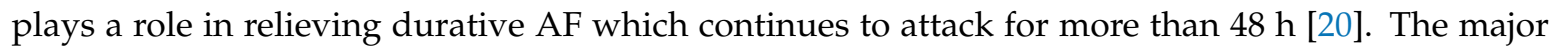
voltage-gated $\mathrm{K}^{+}$channels expressed in the vasculature are Kv1.2, Kv1.5, Kv2.1, and Kv7.4/7.5 [21]. $\mathrm{Kv1.3}$, another Shaker-related family voltage-gated $\mathrm{K}^{+}$channel, is closely related to the $h \mathrm{ERG}$ channels regulated by Kv1.1 [22], which are the important targets influencing the prolongation of $Q$ band to the end of T band (QT) syndrome and torsade pointes attributed to the gain-of-function mutations of clinical candidates whose details are being requested by drug regulatory authorities. Limitations in the ability of high-throughput screening methods to monitor the complex behavior of $h$ ERG have restricted the discovery of activators. It is noteworthy that some inhibitors of Kv1.5 channels listed in Table 1 are not specific voltage-gated $\mathrm{K}^{+}$channels for Kv1.5, and some of which also block Kv1.3 channels (e.g., 4-aminopiridine (2), nifedipine (6), diltiazem (10), tetraethylammonium (11), propofol (24) [23], resveratrol (52) [24], and correolide (55)). Application of these drugs may result in side effects related to the inhibition of Kv1.3 channels like immune suppression, thus more attention should be paid to the toxicity to $h$ ERG-related targets of Kv1.5 developing candidates. Additionally, in the field of immunization [25], nuclear factor erythroid 2-related factor (Nrf2)-induced oxidative stress-inducible protein 1/p62 enhances the inhibition of pulmonary arterial Kv1.5 channels under acute hypoxia, and the 1/p62-Kv1.3-integrin axis provides novel insight into the molecular mechanisms underlying redox-regulated cell signaling in stress-induced biological responses, which broaden future potential directions.

A variety of natural products have been proven to modulate Kv1.5, but the exploration of novel skeleton could be helpful for the current dilemma. Among the isolated compounds, the main types are terpenoids (38-41), alakaloids (42-47), and flavonoids (48-50). Terpenoids are widely reported to inhibit potassium channels [26-28], however, the stability and difficulty in preparation because of the lack of a fluorescence group and the abundance in chiral carbon are worth worrying about in the development. Alkaloids, as well as polypeptides like kaliotoxin (54) and toxins from marine animals like tetrodotoxin, have been disclosed to inhibit ion channel activity, but the toxicity of these types of compounds is also concerning; after all, $h$ ERG toxicity has attracted the attention of the FDA and drugs like bepridil have been withdrawn because of their toxicity [29]. Bioactive flavonoids are also proven to modulate the Kv1.5 channel; among them is quercetin (50), a minor compound and activator of Kv1.5, with the tendency of developing flavonoids and phenols as health care products or food additives.This class of compounds may play a role in the daily prevention against Kv1.5 disease. 


\section{Synthetic Kv1.5 Inhibitors and SAR Investigations}

In this section we collated information about chemical synthesis, pharmacological properties, and SAR investigations in the published literature from 2003 to 2019 and summarized them in a timeline. The previous work was briefly introduced in the description ofthe potential synthetic derivatives and chemical structure of compounds, and the SAR studies are listed in the corresponding figures in the perspective of medicinal chemistry. As we can see, multiple scaffolds include 5-methoxypsoralen $(60,68)$, tetrahydroindolone (62-65), benzopyran sulfonamides (70-72), dihydropyrazolopyrimidine $(73,81)$, and phenylquinazoline (90-92). Compounds (86-88) have been reported to be effective in inhibiting Kv1.5, suggesting potential future directions for investigations about Kv1.5 inhibitors. It is noteworthy that research from Bristol-Myers Squibb has contributed greatly with data about pharmacology and pharmacokinetics of active compounds in blocking Kv1.5, increasing the possibility that we can conquer the diseases targeting Kv1.5. 
Table 1. Active Kv1.5 modulators.

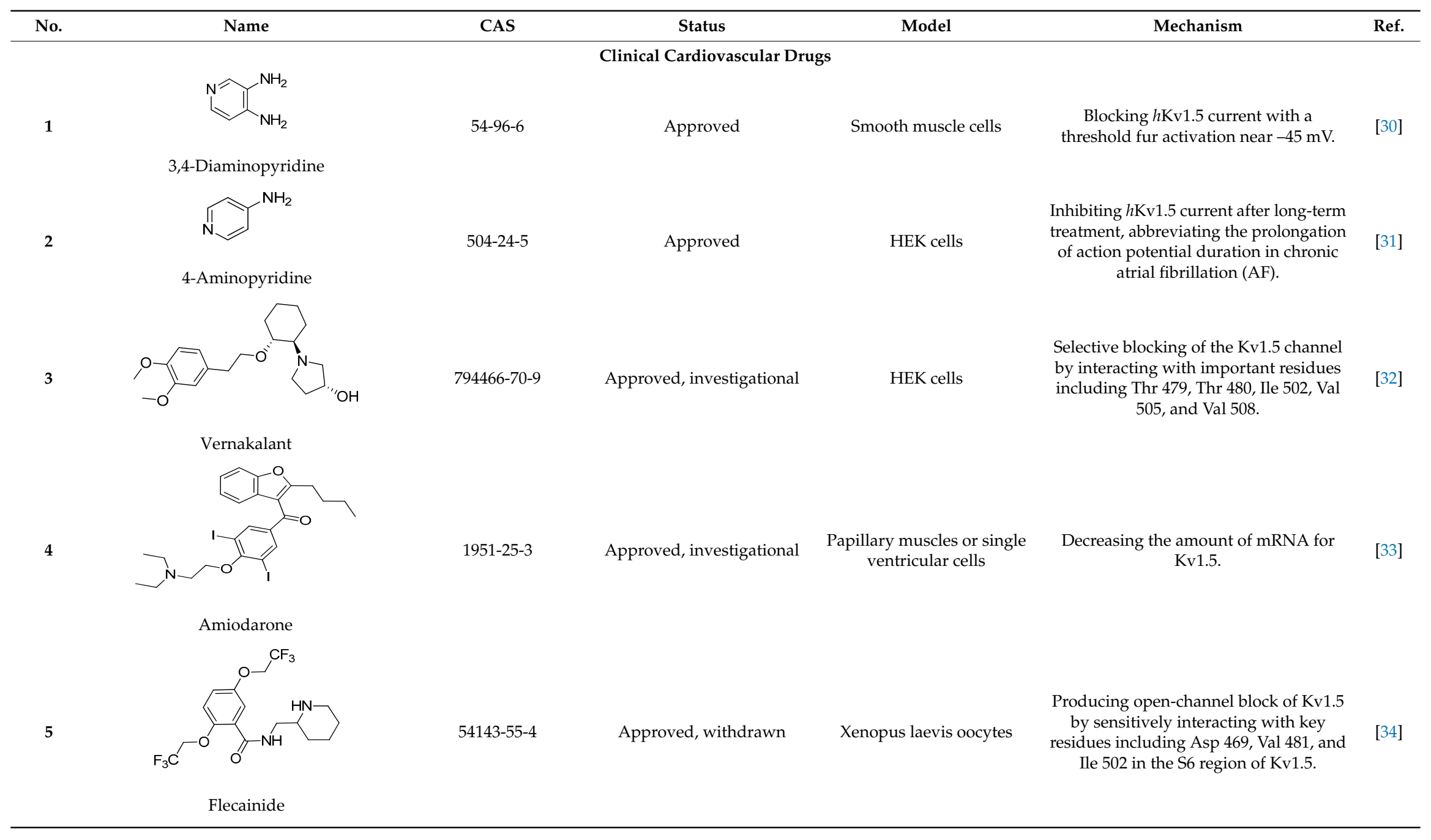


Table 1. Cont.

\begin{tabular}{|c|c|c|c|c|c|c|}
\hline No. & Name & CAS & Status & Model & Mechanism & Ref. \\
\hline 6 & & $21829-25-4$ & Approved & HEK cells & $\begin{array}{c}\text { Blocking } h \mathrm{Kv} 1.5 \text { channels with } 6.3 \mu \mathrm{M} \text { of } \\
\mathrm{K}_{\mathrm{d}} \text { was affected by mutations like Arg } \\
487 \text { similar to those known to affect } \\
\text { outer pore C-type inactivation. }\end{array}$ & [35] \\
\hline 7 & & $54063-53-5$ & Approved & Ltk $^{-}$cells & $\begin{array}{l}\text { Inhibiting } h \mathrm{Kv} 1.5 \text { current with } \mathrm{K}_{\mathrm{d}} \text { value } \\
\text { of } 9.2 \mu \mathrm{M} \text {, showing time-dependent and } \\
\text { dose-dependent manners } \\
\text { simultaneously. }\end{array}$ & [36] \\
\hline 8 & & 86384-10-3 & - & Ltk $^{-}$cells & $\begin{array}{l}\text { Inhibiting } h \mathrm{Kv} 1.5 \text { current with } \mathrm{K}_{\mathrm{d}} \text { value } \\
\text { of } 4.4 \mu \mathrm{M} \text {, showing time-dependent and } \\
\text { dose-dependent manners } \\
\text { simultaneously. }\end{array}$ & [36] \\
\hline 9 & & $56-54-2$ & Approved, investigational & HEK cells & $\begin{array}{l}\text { Producing a voltage-dependent block } \\
\text { between }+30 \text { and }+120 \mathrm{mV}\left(\mathrm{K}_{\mathrm{d}} \text { at }+60\right. \\
\mathrm{mV}=7.2 \mu \mathrm{M}) \text { with an equivalent } \\
\text { electrical distance in the steady state. }\end{array}$ & [37] \\
\hline & & & & & & \\
\hline
\end{tabular}


Table 1. Cont.

\begin{tabular}{|c|c|c|c|c|c|c|}
\hline No. & Name & CAS & Status & Model & Mechanism & Ref. \\
\hline 10 & & 42399-41-7 & Approved, investigational & $\mathrm{CHO}$ cells & $\begin{array}{l}\text { Blocking } h \mathrm{Kv} 1.5 \text { channels, in a } \\
\text { frequency-dependent manner exhibiting } \\
\text { a biphasic dose-response curve ( } \mathrm{IC}_{50}: 4.8 \\
\mathrm{nM} \text { and } 42.3 \mu \mathrm{M}) \text { by binding to the open } \\
\text { and inactivated state of the channels. }\end{array}$ & [38] \\
\hline & & & & & & \\
\hline 11 & & $66-40-0$ & $\begin{array}{l}\text { Experimental, } \\
\text { investigational }\end{array}$ & BT-474 breast cancer cell & $\begin{array}{l}\text { Blocking } h \mathrm{Kv} 1.5 \text { channels in a delayed } \\
\text { rectifier manner. }\end{array}$ & [39] \\
\hline 12 & & 68379-03-3 & - & $\mathrm{CHO}$ cells & $\begin{array}{l}\text { Inhibiting } h \mathrm{Kv} 1.5 \text { current with } \\
\text { concentration-dependent acceleration of } \\
\text { the apparent channel inactivation in } \\
\text { both outside-out and inside-out patches. }\end{array}$ & [40] \\
\hline 13 & & $163163-23-3$ & - & $\mathrm{CHO}$ cells & $\begin{array}{l}\text { Blocking } h \mathrm{Kv} 1.5 \text { current stereoselectivity, } \\
\text { the results showed that (-)-[3R, } 4 S] \text { was } \\
\text { more potent than the (-)-enantiomer. }\end{array}$ & [41] \\
\hline & tanol 2 & & & & & \\
\hline
\end{tabular}


Table 1. Cont.

\begin{tabular}{|c|c|c|c|c|c|c|}
\hline No. & Name & CAS & Status & Model & Mechanism & Ref. \\
\hline \multirow[t]{2}{*}{14} & & $64706-54-3$ & Approved, withdrawn & HEK cells & $\begin{array}{l}\text { Inhibiting the } h \mathrm{Kv} 1.5 \text { channel current } \\
\text { with } \mathrm{IC}_{50} \text { value of } 6.6 \mu \mathrm{M} \text {. }\end{array}$ & [42] \\
\hline & & & & & & \\
\hline \multirow[b]{2}{*}{15} & & & Other Clinical Drugs & & & \\
\hline & & $120014-06-4$ & Approved & HEK cells & $\begin{array}{l}\text { Resulting in a rapid and reversible block } \\
\text { of Kv1.5 currents (IC } \mathrm{I}_{50}: 72.5 \mu \mathrm{M} \text { ) with a } \\
\text { significant delay in the duration of } \\
\text { activation and deactivation, and the } \\
\text { outer mouth region proved to be the } \\
\text { target site. }\end{array}$ & [15] \\
\hline 16 & & 61869-08-7 & Approved, investigational & $\mathrm{CHO}$ cells & $\begin{array}{l}\text { Slowing the deactivation time course, } \\
\text { resulting in a tail crossover phenomenon } \\
\text { when the tail currents, recorded in the } \\
\text { presence and absence of paroxetine, } \\
\text { were superimposed. }\end{array}$ & [43] \\
\hline \multirow[t]{2}{*}{17} & & 54910-89-3 & Approved, vet approved & $\begin{array}{l}\text { Human Pulmonary Artery } \\
\text { Smooth Muscle Cells }\end{array}$ & $\begin{array}{l}\text { Protecting against big endothelin-1 } \\
\text { induced anti-apoptosis and rescued } \\
\text { Kv1.5 channels in human pulmonary } \\
\text { arterial smooth muscle cells. }\end{array}$ & [44] \\
\hline & oxetin & & & & & \\
\hline
\end{tabular}


Table 1. Cont.

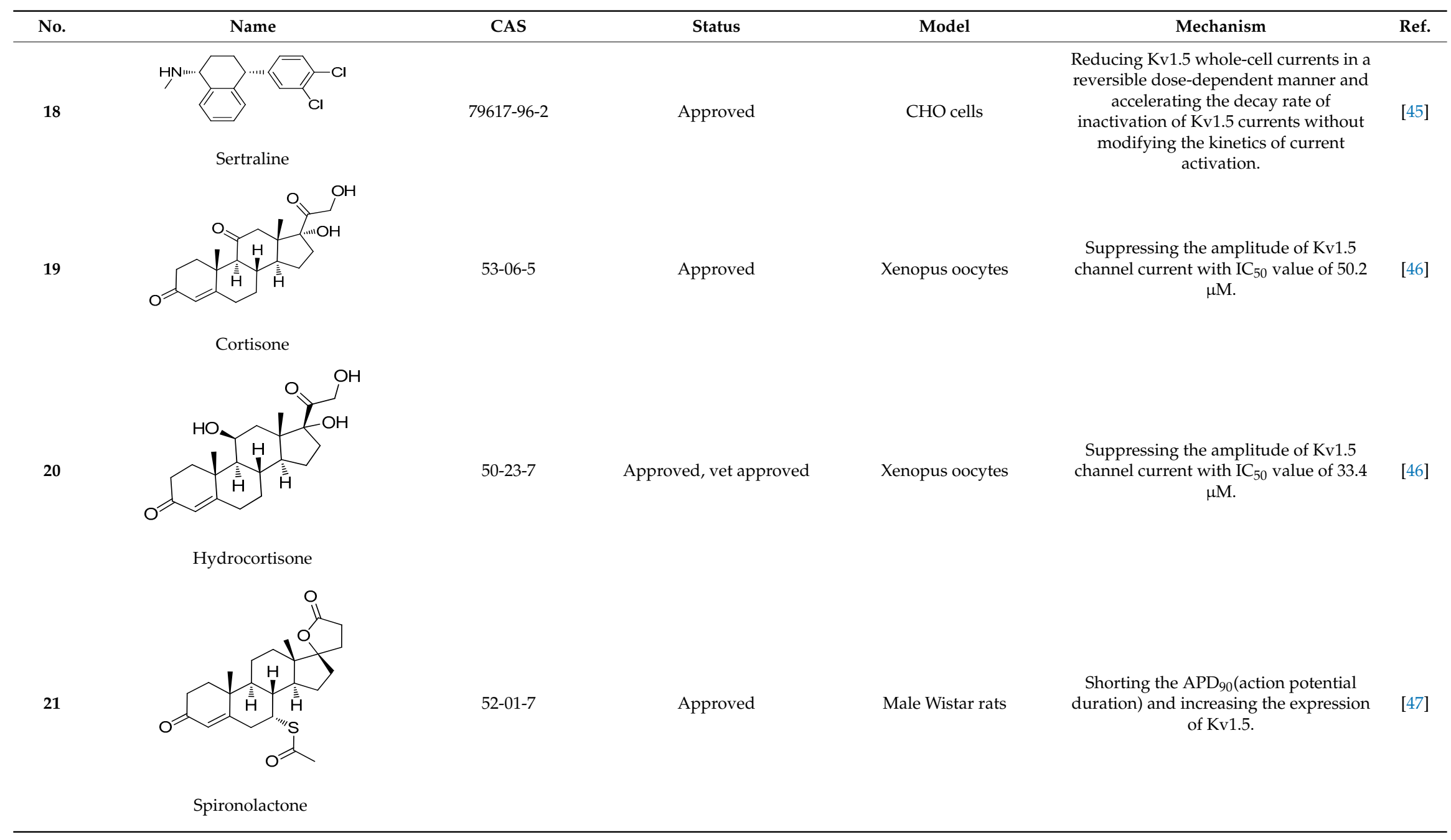


Table 1. Cont.

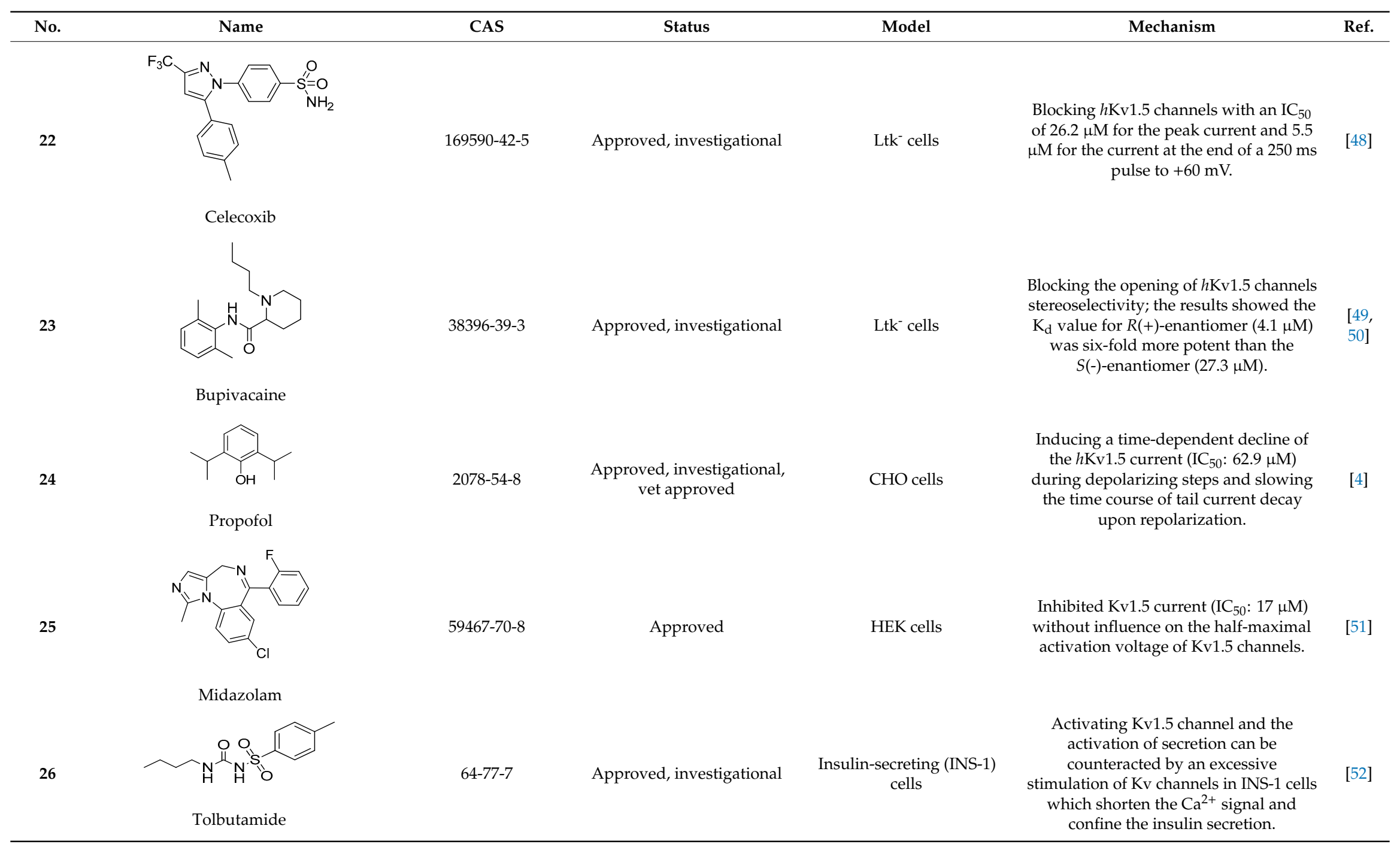


Table 1. Cont.

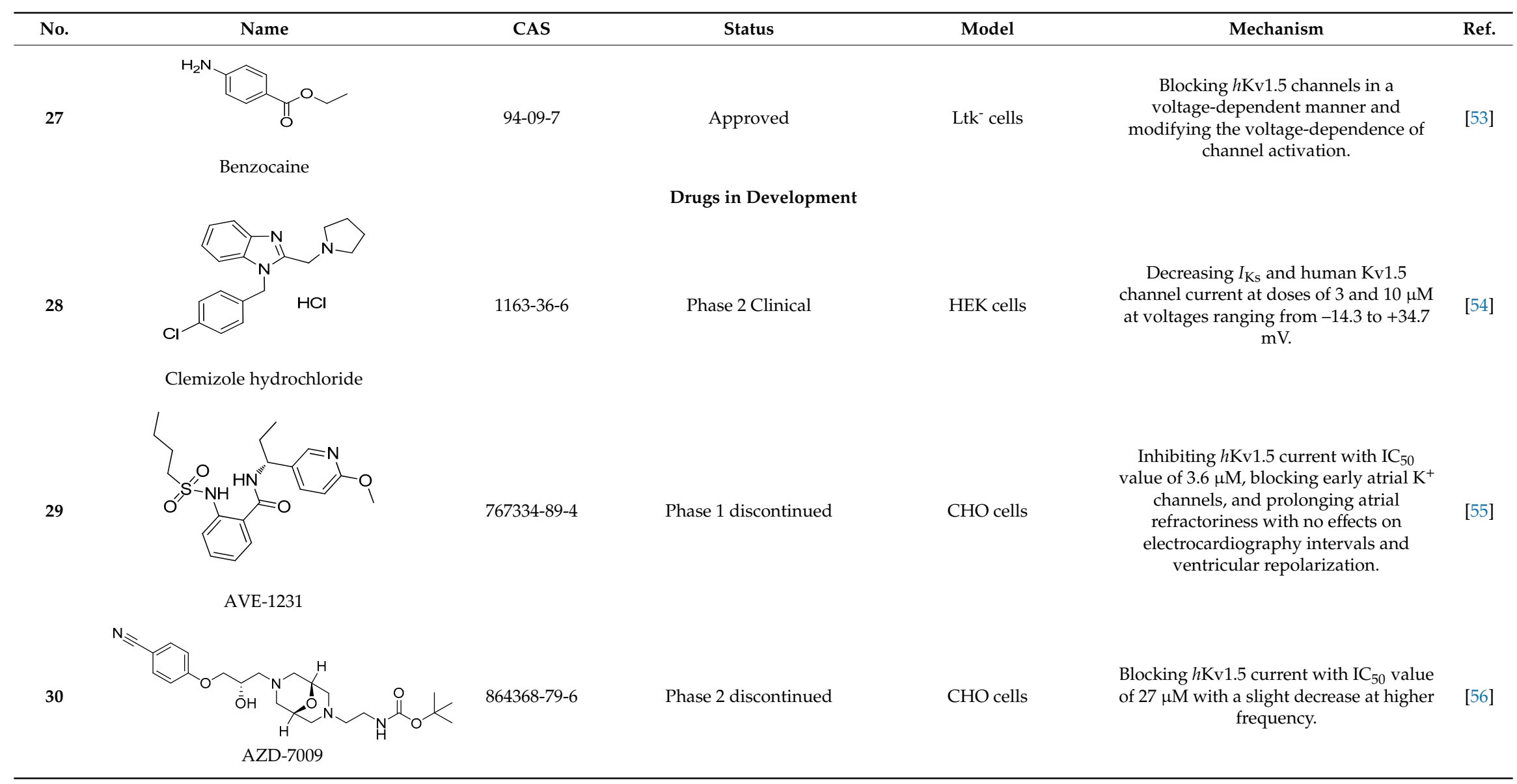


Table 1. Cont.

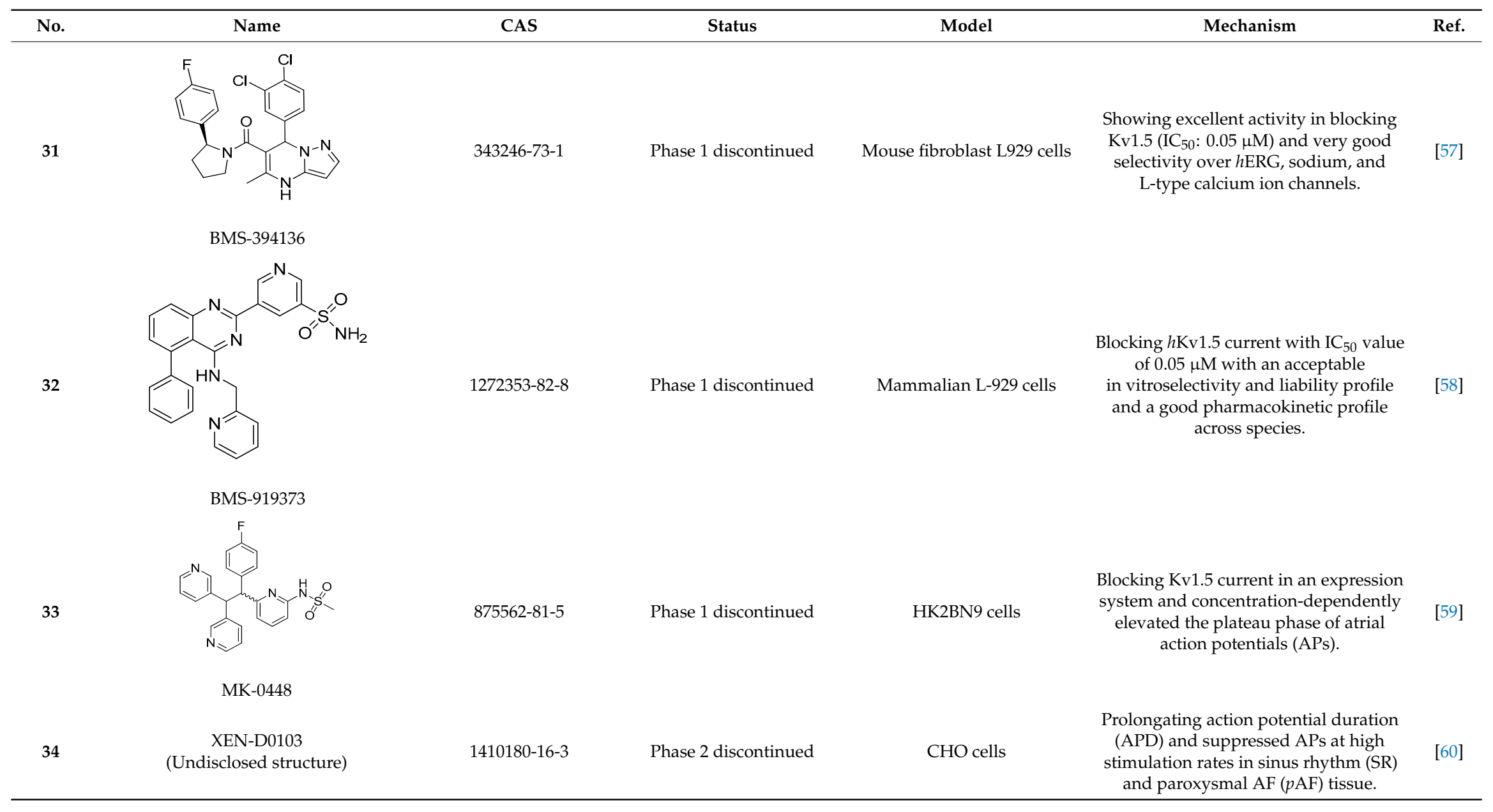


Table 1. Cont.

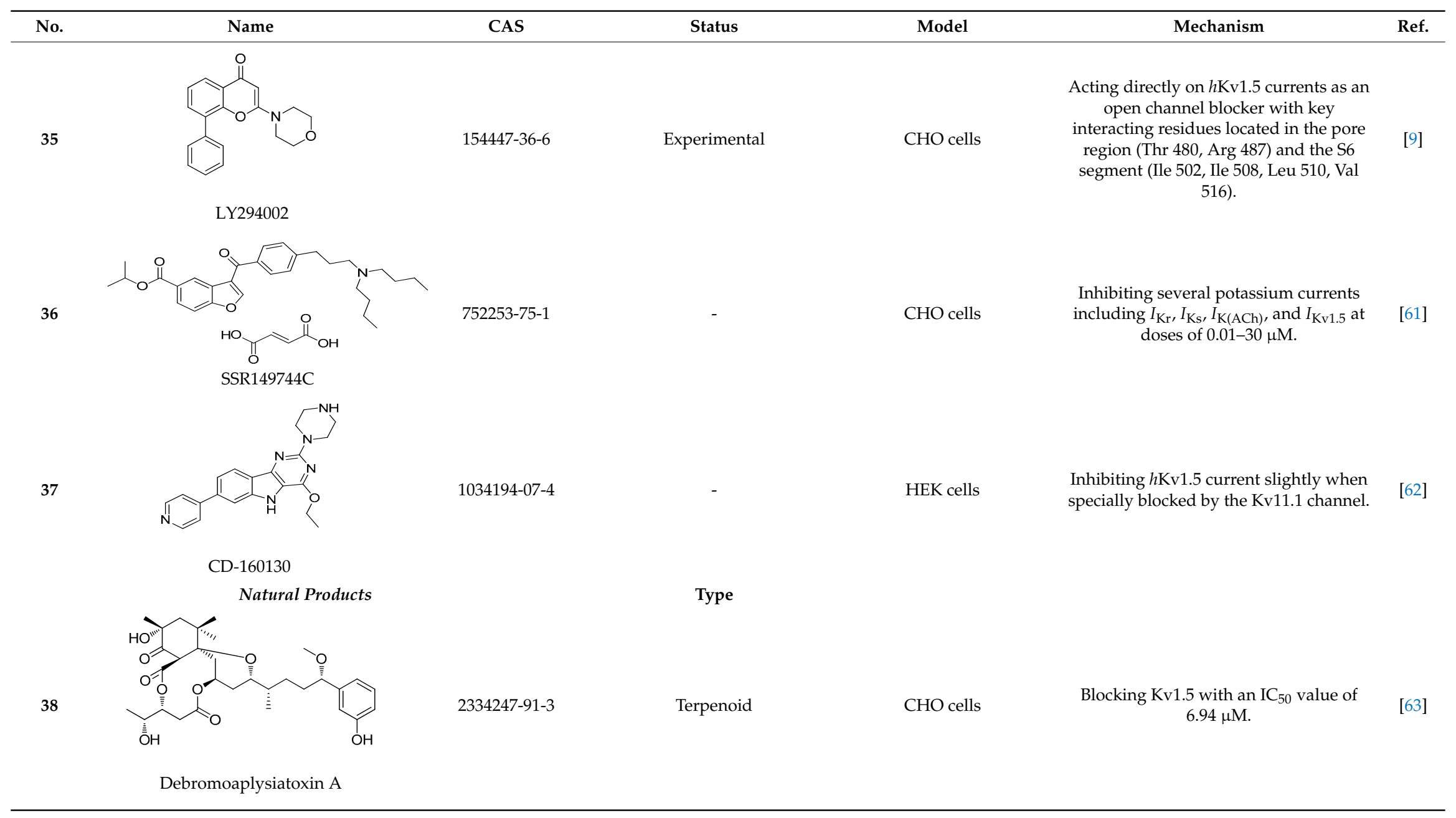


Table 1. Cont

\begin{tabular}{|c|c|c|c|c|c|c|}
\hline No. & Name & CAS & Status & Model & Mechanism & Ref. \\
\hline \multirow[t]{2}{*}{39} & & 2334247-94-6 & Terpenoid & $\mathrm{CHO}$ cells & $\begin{array}{l}\text { Blocking Kv1.5 with an } \mathrm{IC}_{50} \text { value of } \\
0.30 \mu \mathrm{M} .\end{array}$ & [63] \\
\hline & blys & & & & & \\
\hline \multirow[t]{2}{*}{40} & & $57444-62-9$ & Terpenoid & C6 glioma cells & $\begin{array}{l}\text { Inhibiting the } h \mathrm{Kv} 1.5 \text { current in time and } \\
\text { dose-dependent manners. }\end{array}$ & [64] \\
\hline & era & & & & & \\
\hline 41 & & $13018-10-5$ & Terpenoid & Ltk cells & $\begin{array}{l}\text { Inhibiting the } h \mathrm{Kv} 1.5 \text { current in time- } \\
\text { and voltage-dependent manners, with } \\
\text { an IC } 50 \text { value of } 2.51 \mu \mathrm{M} \text { at }+60 \mathrm{mV} \\
\text { accelerated the inactivation kinetics of } \\
\text { the } h \mathrm{Kv} 1.5 \text { channel and slowed the } \\
\text { deactivation kinetics of the } h \mathrm{Kv} 1.5 \\
\text { current, resulting in a tail crossover } \\
\text { phenomenon. }\end{array}$ & [65] \\
\hline
\end{tabular}


Table 1. Cont.

\begin{tabular}{|c|c|c|c|c|c|c|}
\hline No. & Name & CAS & Status & Model & Mechanism & Ref. \\
\hline 42 & & $1394-48-5$ & Alkaloid & Guinea pigs & $\begin{array}{c}\text { Blocking I-Kv1.5 slightly with a ratio of } \\
20.6 \% \text { at a dosage of } 200 \mu \mathrm{M} \text {. }\end{array}$ & [66] \\
\hline & te & & & & & \\
\hline 43 & Lobe & $90-69-7$ & Alkaloid & HEK cells & $\begin{array}{l}\text { Accelerating the decay rate of Kv1.5 } \\
\text { inactivation, decreased the current } \\
\text { amplitude at the end of the pulse in a } \\
\text { concentration-dependent manner with } \\
\text { an } \mathrm{IC}_{50} \text { value of } 15.1 \mu \mathrm{M} \text {. }\end{array}$ & [67] \\
\hline 44 & & $4360-12-7$ & Alkaloid & Xenopus oocytes & $\begin{array}{c}\text { Inhibiting Kv1.5 with an } \mathrm{IC}_{50} \text { of } 1.70 \mu \mathrm{M} \\
\text { in Xenopus expression system, resulting } \\
\text { in a mild leftward shift of Kv1.5 } \\
\text { activation curve. }\end{array}$ & [68] \\
\hline 45 & & $58-74-2$ & Alkaloid & Ltk $^{-}$cells & $\begin{array}{c}\text { Blocking } h \mathrm{Kv} 1.5 \text { channels and native } \\
h \mathrm{Kv} 1.5 \text { channels in a concentration-, } \\
\text { voltage-, state-, and time-dependent } \\
\text { manner. }\end{array}$ & [69] \\
\hline & & & & & & \\
\hline
\end{tabular}


Table 1. Cont.

\begin{tabular}{|c|c|c|c|c|c|c|}
\hline No. & Name & CAS & Status & Model & Mechanism & Ref. \\
\hline 46 & & $2934-97-6$ & Alkaloid & HEK cells & $\begin{array}{c}\text { Blocking Kv1.5 currents } \\
\text { dose-dependently with an } \mathrm{IC}_{50} \text { value of } \\
53.2 \mu \mathrm{M} \text { inhibited the delayed rectifier } \\
\text { effect of Kv1.5 resulting in a potential } \\
\text { left shift of the inactivation curve. }\end{array}$ & [70] \\
\hline 47 & & $302-27-2$ & Alkaloid & Xenopus laevis oocytes & $\begin{array}{l}\text { Producing a voltage-, time-, and } \\
\text { frequency-dependent inhibition of Kv1.5 } \\
\left(\mathrm{IC}_{50}: 0.796 \mu \mathrm{M}\right)\end{array}$ & [71] \\
\hline 48 & & $529-44-2$ & Flavonoid & HEK cells & $\begin{array}{l}\text { Inhibiting } I_{\text {kur }} \text { and the expression of } \\
h K v 1.5 \text { in a dose-, time-, and } \\
\text { frequency-dependent manner. }\end{array}$ & [72] \\
\hline 49 & $c$ & $5631-70-9$ & Flavonoid & HEK cells & $\begin{array}{l}\text { Suppressing } h \mathrm{Kv} 1.5 \text { current in HEK } 293 \\
\text { cell line }\left(\mathrm{IC}_{50}: 6.4 \mu \mathrm{M}\right) \text { and the } \\
\text { ultra-rapid delayed rectify } \mathrm{K}^{+} \text {current } \\
I_{\mathrm{Kur}} \text { in human atrial myocytes (IC } \mathrm{I}_{50}: 8.0 \\
\mu \mathrm{M} \text { ) by binding to open channels in a } \\
\text { use- and frequency-dependent manner. }\end{array}$ & [73] \\
\hline
\end{tabular}


Table 1. Cont.

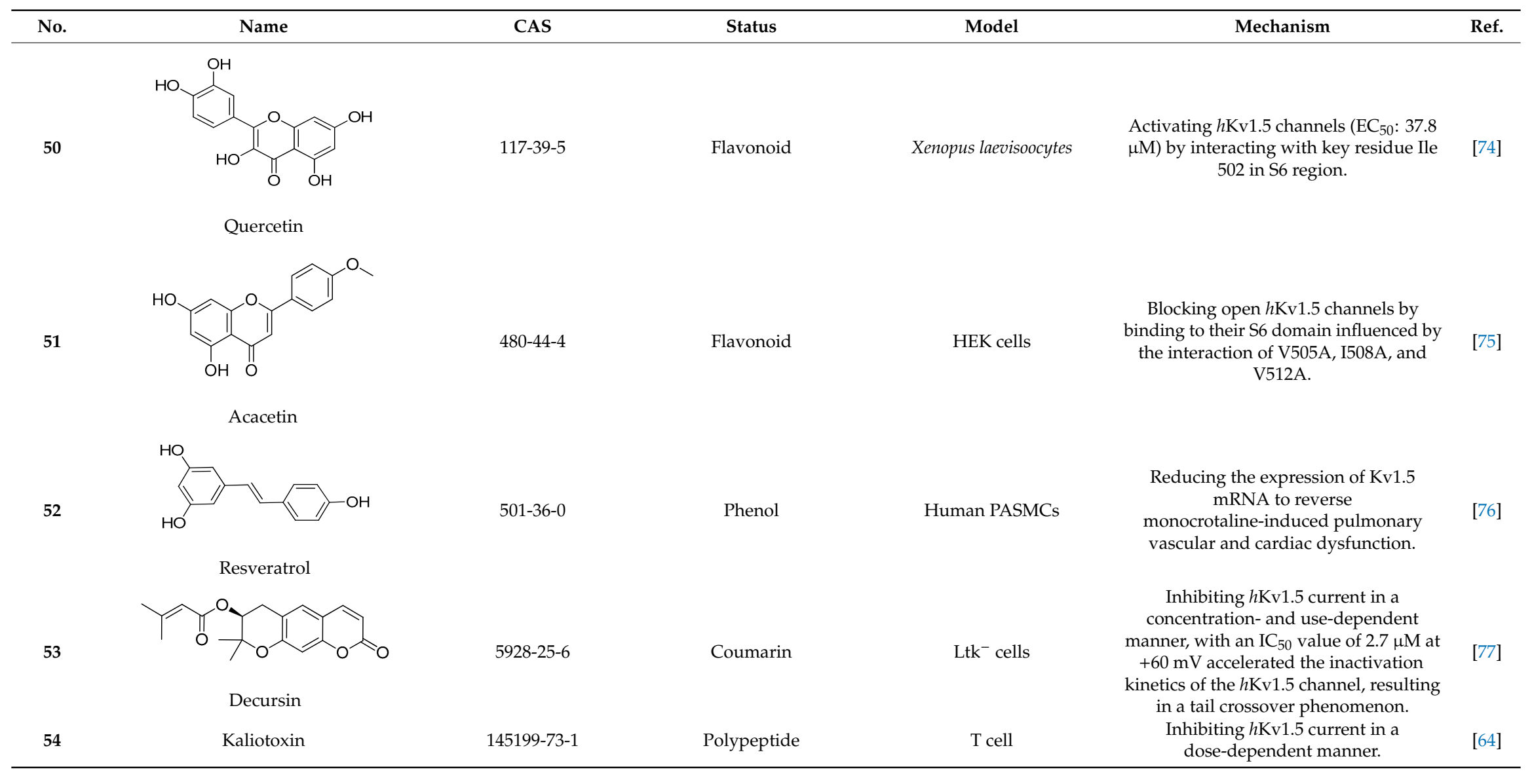


Table 1. Cont.

\begin{tabular}{|c|c|c|c|c|c|c|}
\hline No. & Name & CAS & Status & Model & Mechanism & Ref. \\
\hline 55 & & 190017-00-6 & Nor-triterpenoid & $\mathrm{CHO}$ cells & $\begin{array}{l}\text { Inhibiting Kv1.5 with an } \mathrm{IC}_{50} \text { of } 1.77 \mu \mathrm{M} \\
\text { and influenced by the mutations T480A, } \\
\text { V505A, I508A, as well as V516A. }\end{array}$ & [78] \\
\hline & rreolid & & & & & \\
\hline \multirow[t]{2}{*}{56} & & $107-35-7$ & Amino acid & Male Wistar rats & $\begin{array}{l}\text { Down-regulating the mRNA expression } \\
\text { level of Kv1.5. }\end{array}$ & [79] \\
\hline & Taurine & & & & & \\
\hline
\end{tabular}


In 2003, Peukert and co-workers [80] synthesized a series of ortho-disubstituted bisaryl compounds as blockers of the Kv1.5 channel. Among the derivatives, the most potent compounds $57\left(\mathrm{IC}_{50}: 0.7 \mu \mathrm{M}\right)$ and $58\left(\mathrm{IC}_{50}: 0.16 \mu \mathrm{M}\right)$ inhibited the Kv1.5 channel with sub-micromolar half-blocking concentrations and displayed three fold selectivity over Kv1.3 and no significant effect on the $h$ ERG channel and sodium currents (Figure 3).

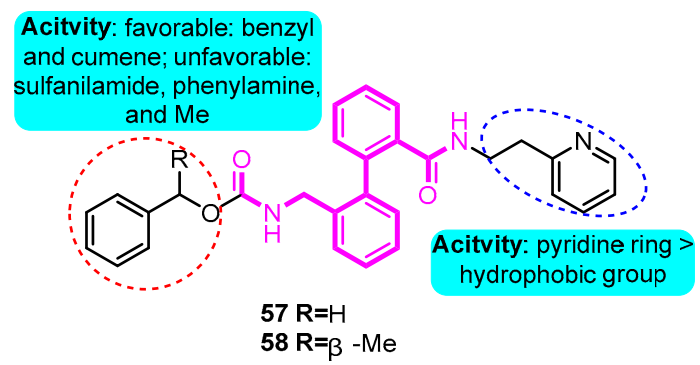

Figure 3. Biphenyl derivatives.

In 2004, Peukert et al. [81] synthesized several anthranilic amides as novel blockers of the Kv1.5 channel. The most hopeful analogue 59 showed moderate $\mathrm{Kv} 1.5$ inhibition $\left(\mathrm{IC}_{50}: 0.7 \mu \mathrm{M}\right)$ with good oral bioavailability, however, no significant effect on the $I_{\mathrm{Kr}}$ current of 59 was detected (Figure 4).

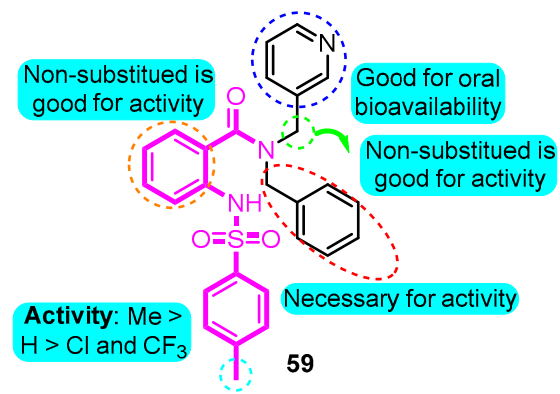

Figure 4. Anthranilic amides.

Inspired from the precursor 5-methoxypsoralen isolated from Rutagraveolens, Schmitz and colleagues [82] prepared a series of phenoxyalkoxypsoralen analogues and evaluated their voltage-gated ion channel blocker potency. The most potent and "druglike" compound of this series, 5-(4-phenoxybutoxy) psoralen (PAP-1, 60), blocks Kv1.3 in a use-dependent manner, with a Hill coefficient of 2 and an $\mathrm{EC}_{50}$ of $2 \mathrm{nM}$, by preferentially binding to the C-type inactivated state of the channel. PAP-1 is 23 fold selective over Kv1.5, 33-125 fold selective over other Kv1 family channels, and 500-7500 fold selective over Kv2.1, Kv3.1, Kv3.2, Kv4.2, hERG, calcium-activated K channels, Na, $\mathrm{Ca}$, and $\mathrm{Cl}$ channels. PAP-1 does not exhibit cytotoxic or phototoxic effects, is negative in the Ames test, and affects cytochrome P450-dependent enzymes only at micromolar concentrations (Figure 5).

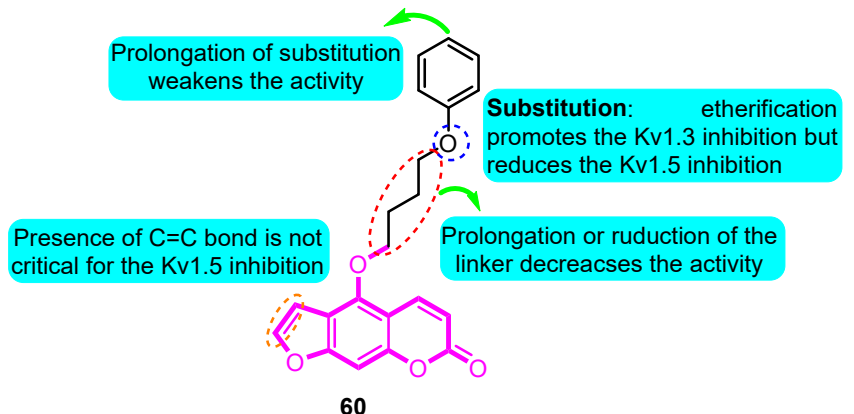

Figure 5. Phenoxyalkoxypsoralen analogues. 
In 2006, Blass et al. [83] synthesized a cluster of (2-phenethyl-2H-1,2,3-triazol-4-yl) (phenyl) methanone and examined for utility as Kv1.5 channel blockers for the treatment of atrial fibrillation. The results showed that $\mathrm{O}$ substitution in the 4-position of the acetophenone-derived portion of the scaffold is highly favored, and the most active compound $\mathbf{6 1}$ blockaded Kv1.5 for $99 \%$ at a concentration of $1 \mu \mathrm{M}$ (Figure 6).

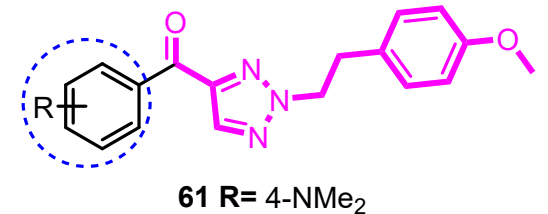

Activity: 4-position of substitutions are favoured and lipophilicity is well tolerated, but the difference between EDGs and EWGs is not substantial.

Figure 6. (2-phenethyl-2H-1,2,3-triazol-4-yl)(phenyl) methanones.

Fluxe and co-workers [84] synthesized multiple tetrahydroindolone-derived carbamates as potent Kv1.5 blockers. The most promising analogues 62 and 63 exhibited the strongest Kv1.5 inhibitory effect with $\mathrm{IC}_{50}$ values of 67 and $21 \mathrm{nM}$, respectively. They were also very selective over $h \mathrm{ERG}(>450$ fold $)$ and L-type calcium channels (> 450 fold) (Figure 7 ).

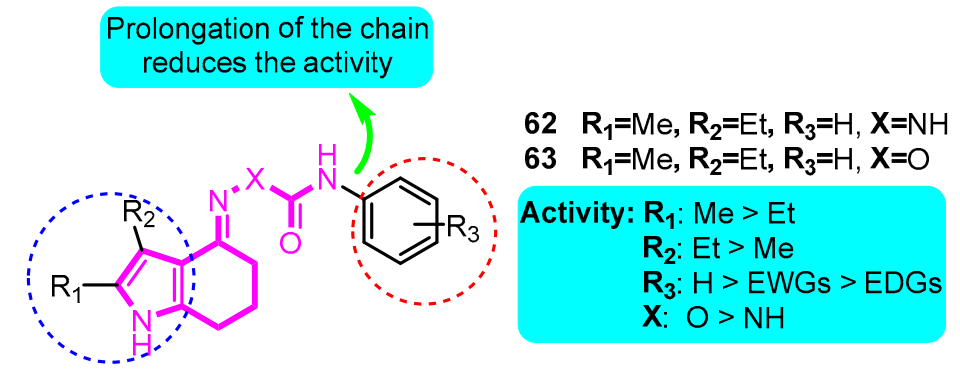

Figure 7. Tetrahydroindolone-derived carbamates.

Subsequently, Wu et al. [85] designed and synthesized tetrahydroindolone derived semicarbazones as selective Kv1.5 blockers. Compounds 64 and 65 showed good selectivity for the blockade of Kv1.5 ( $\mathrm{IC}_{50}: 0.13 \mu \mathrm{M}$ for two compounds), moreover, in an anesthetized pig model, compounds 64 and 65 increased atrial ERP by about $28 \%$ and $18 \%$, respectively, in the right atrium without affecting ventricular ERP (Figure 8).

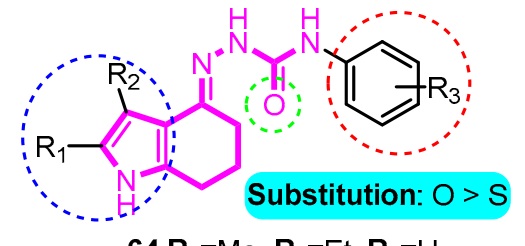

$64 \mathbf{R}_{\mathbf{1}}=\mathrm{Me}, \mathbf{R}_{\mathbf{2}}=\mathrm{Et}, \mathbf{R}_{\mathbf{3}}=\mathrm{H}$

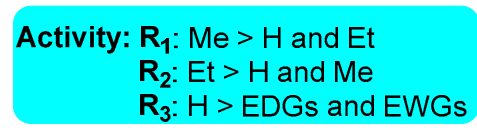

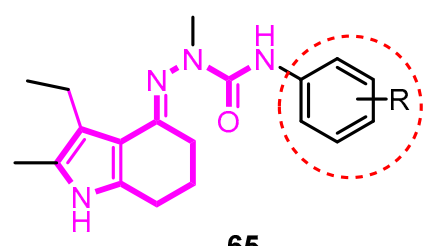

65

Activity: $4-\mathrm{Cl}>3-\mathrm{Cl}>4-\mathrm{Ac}>4-\mathrm{SMe}>\mathrm{H}$

Figure 8. Tetrahydroindolone-derived semicarbazones.

Based on a diisopropyl amide scaffold, a series of potent Kv1.5 ion channel antagonists were synthesized by Nanda and colleagues [86]. The most active derivative 66, which was a single active 
enantiomer of the diastereomerically pure racemic analog, exhibited significant atrial-selective effects in an in vivo model $\left(\mathrm{IC}_{50}: 150 \mathrm{nM}\right)$ (Figure 9).

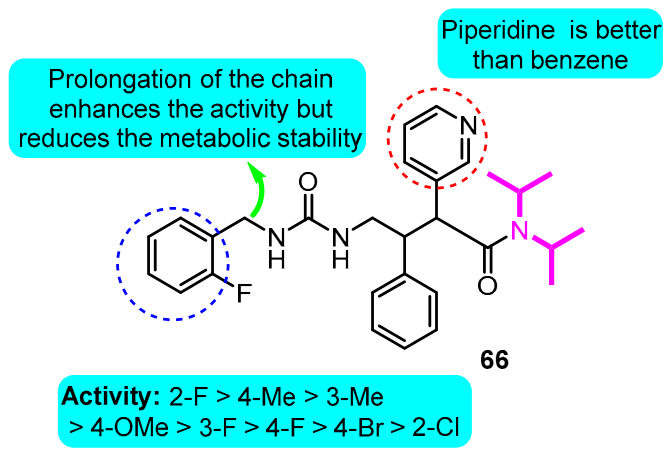

Figure 9. Diisopropyl amide derivatives.

Trotter and co-workers [87] designed and synthesized a group of isoquinoline-3-nitriles as orally Kv1.5 antagonists for the treatment of AF. The ethanolamide derivative 67 exhibited improved potency (Kv1.5 HT-Clamp IC $50: 60 \mathrm{nM}$ ), excellent selectivity versus $h$ ERG, and good pharmacokinetic properties. Rat EP experiments confirmed that the compound potently increased ARP without significant effects on $\mathrm{AVRP}^{-}$(Figure 10).

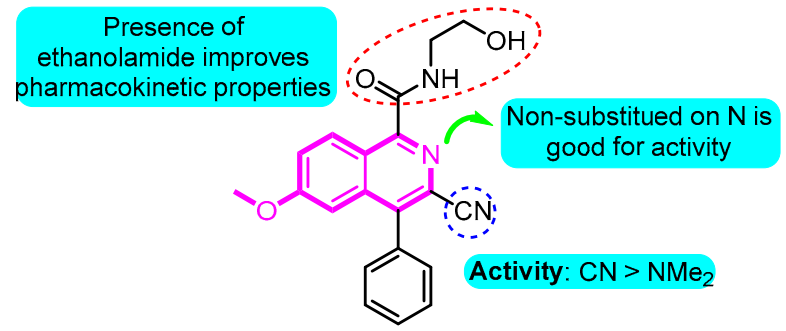

67

Figure 10. Isoquinoline-3-nitriles.

In 2007, Eun et al. [88] synthesized multiple psoralen derivatives as $h \mathrm{Kvl} .5$ channel blockers. Among them, compound 68 was the most potent in blocking $h \mathrm{Kv} 1.5\left(\mathrm{IC}_{50}: 27.4 \mathrm{nM}\right)$, much stronger than the lead compound psoralen. Compound 68 accelerated the inactivation kinetics of the $h \mathrm{Kvl} .5$ channel and slowed the deactivation kinetics of the $h \mathrm{Kv} 1.5$ current resulting in a tail crossover phenomenon. Compound 68 inhibited the $h \mathrm{Kvl} .5$ current in a use-dependent manner (Figure 11).

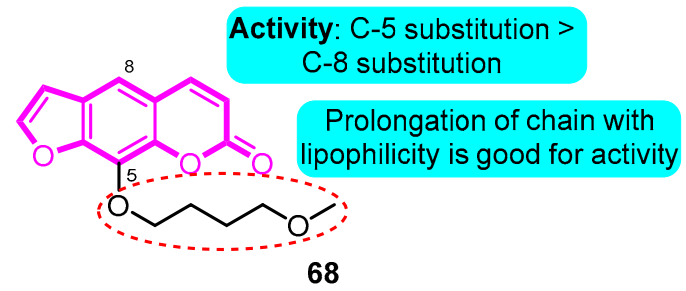

Figure 11. Psoralen derivatives.

Jackson and co-workers [89] prepared several classes of thiazolidine-based Kv1.5 blockers. The most promising analogue 69 derived from 3,4-dimethylacetophenone exhibited the strongest inhibitory effect with an $\mathrm{IC}_{50}$ value of $69 \mathrm{nM}$ (Figure 12). 


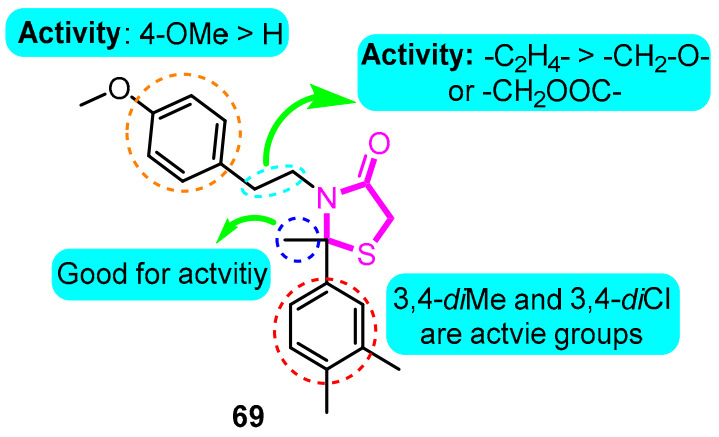

Figure 12. Thiazolidine derivatives.

Lloyd et al. [90] synthesized a series of benzopyran sulfonamides and determined Kv1.5 potassium channel blocking effects. Among the productions, derivative $\mathbf{7 0}$ exhibited the most significant activity $\left(\mathrm{IC}_{50}: 57 \mathrm{nM}\right.$ ), and a moderate inhibition (35\%) of $h \mathrm{ERG}$ at a concentration of $10 \mu \mathrm{M}$ (Figure 13).

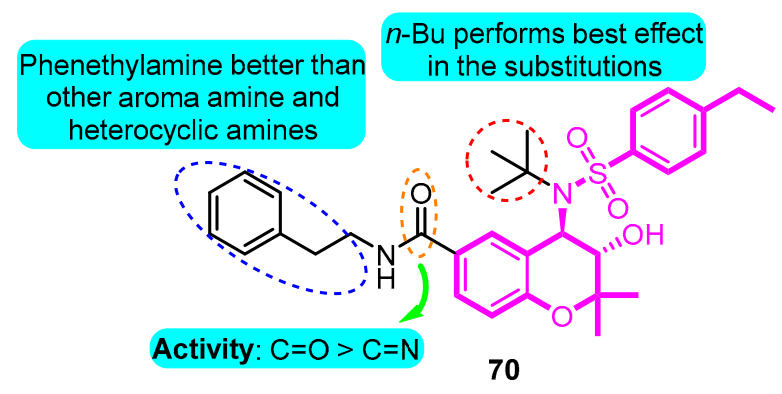

Figure 13. Benzopyran sulfonamides.

In 2008, benzopyran sulfonamides derivatives were further investigated [91]. Compound 71 and 72 were considered as the most active derivatives in the two series of compounds with $\mathrm{IC}_{50}$ values of 46 and $378 \mathrm{nM}$ in the inhibition of current in a L-929 cell model, respectively. Additionally, at the concentration of $1.0 \mu \mathrm{M}$, compound 72 displayed the most significant inbitory effect in the current of L-929 cells with an inhibitory ratio of $89 \%$ (Figure 14).
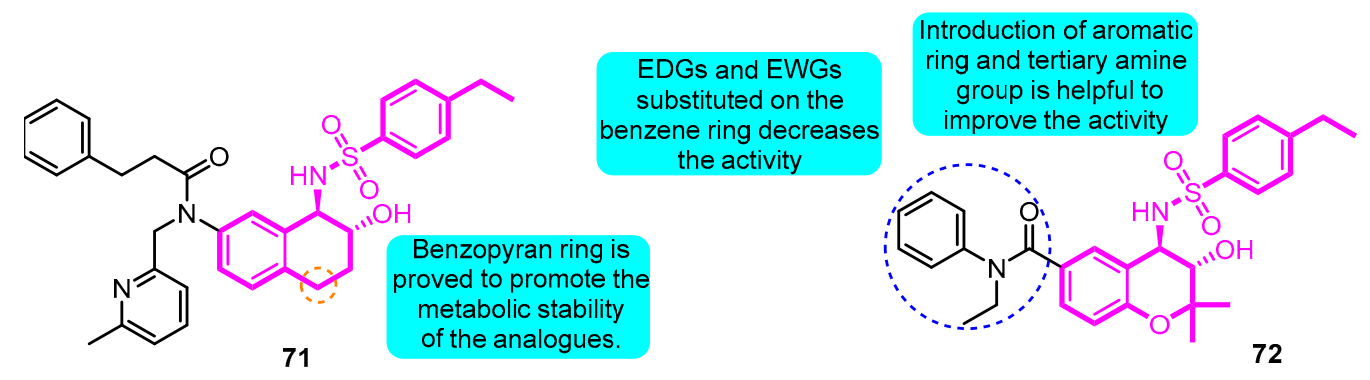

Figure 14. Thiazolidine derivatives.

Vaccaro and co-workers [90] synthesized a series of dihydropyrazolopyrimidine analogues as Kv1.5 inhibitors. The most promising compound 73 showed the best potential in suppressing Kv1.5, with inhibitory effects on $h$ ERG $(69 \%)$ and $I_{\mathrm{Na}}{ }^{10}(42 \%)$ at a concentration of $10 \mu \mathrm{M}$ (Figure 15). 


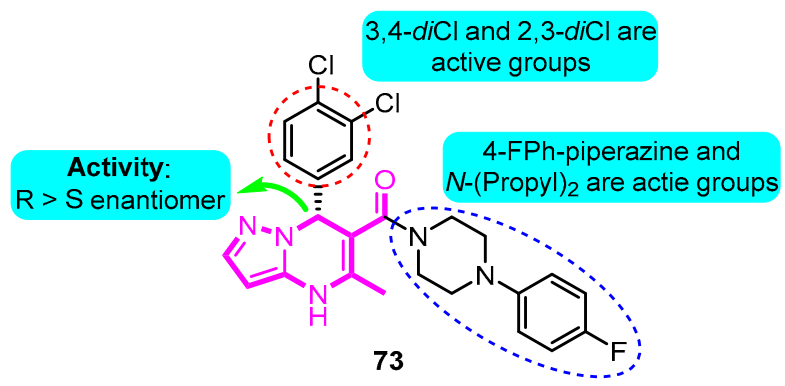

Figure 15. Dihydropyrazolopyrimidine derivatives.

In 2008, Gross and co-workers [92] synthesized aryl sulfonamido tetralin as a Kv1.5 inhibitor according to the basis of previous work. Among the productions, compound $\mathbf{7 4}$ exhibited remarkable Kv1.5 inhibitions with an $\mathrm{IC}_{50}$ value of $90 \mathrm{nM}$; in addition, moderate $h \mathrm{ERG}$ inhibition was detected at the dose of $10 \mu \mathrm{M}(39 \%)$, indicating the potential for further development of clinical candidates (Figure 16).

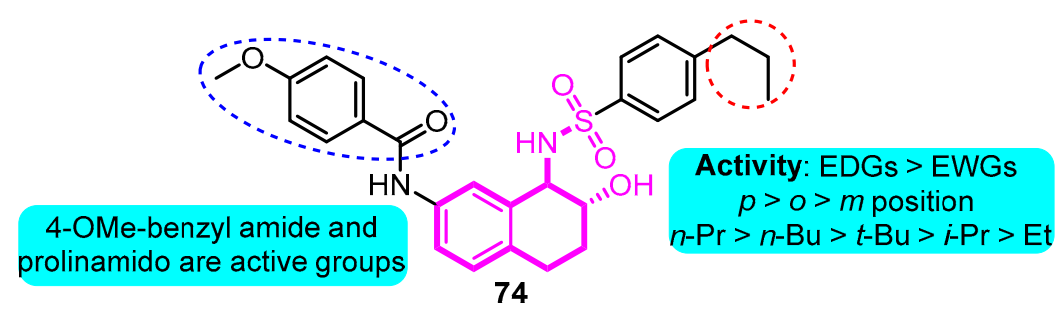

Figure 16. Aryl sulfonamido tetralin derivatives.

According to the structure of marketed drugs amiodarone and vernakalant, Blass et al. [93] synthesized a series of imidazolidinone derivatives as a potential treatment for atrial arrhythmia. KVI-020/WYE-160020 (75) exhibited the efficacy in clinically relevant models of AF and mechanistic models of the cardiac action potential with acceptable pharmacokinetic and pharmaceutical properties. The pharmacology $\mathrm{IC}_{50}$ values for compound 75 in Kv1.5, $h \mathrm{ERG}$, Nav1.5, Cav1.3, Cav1.2, Kv1.1, Kv1.3, and Kv4.3 were $0.48,15.1,>30,23.4,>30,2.66,1.41$, and $3.87 \mu \mathrm{M}$ in vitro, respectively (Figure 17).

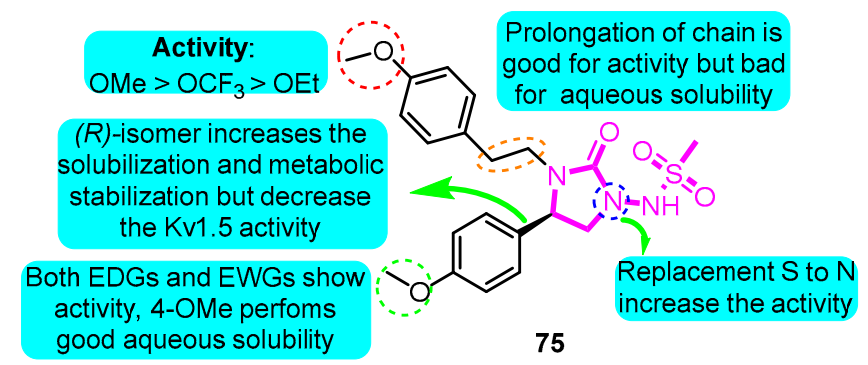

Figure 17. Structure-activity relationship (SAR) of imidazolidinone derivatives.

In 2010, Lloyd and co-workers [58] developed a series of pyrazolodihydropyrimidines as potent and selective Kv1.5 blockers based on previous studies. The most promising analogue BMS-394136 (76) displayed excellent activity in blocking $\mathrm{Kv} 1.5\left(\mathrm{IC}_{50}: 50 \mathrm{nM}\right)$ and very good selectivity over $h \mathrm{ERG}$, sodium, and L-type calcium ion channels with good pharmacokinetic parameters (Figure 18). 


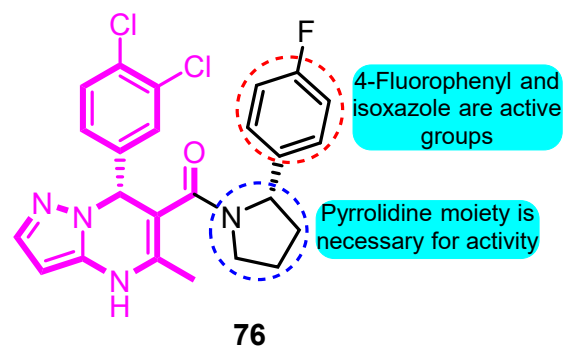

Figure 18. SAR of pyrazolodihydropyrimidines.

In 2012, Blass [94] prepared several heteroarylsulfonamides as Kv1.5 inhibitors. The active analogues 77, 78 and 79 exhibited 100\% inhibition of Kv1.5 using stably transfected HEK293 cells and the FLIPR potassium ion channel assay, suggesting good potential for further investigation (Figure 19).

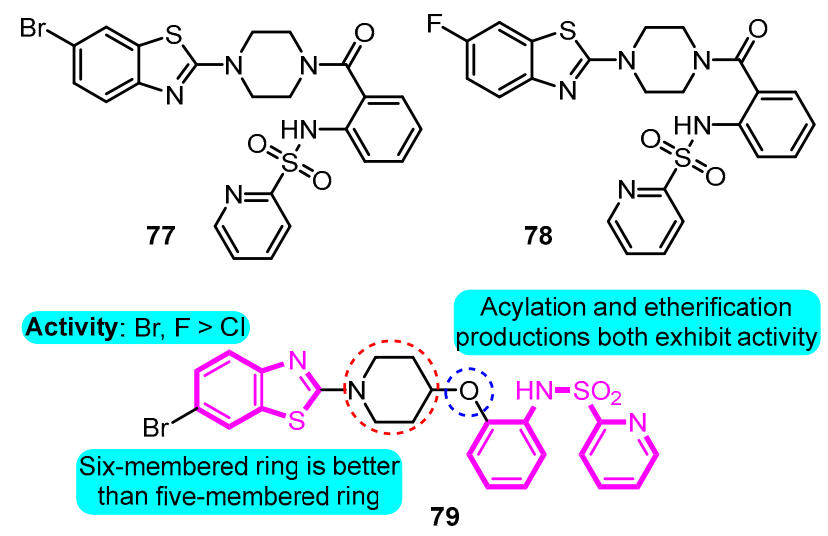

Figure 19. SAR of heteroarylsulfonamides.

Finlay and colleagues [95] prepared several dihydropyrazolo[1,5-a]pyrimidine derivatives. Among the synthetic compounds, compound $\mathbf{8 0}$ showed potential to be a selective $I_{\text {Kur }}$ inhibitor with Kv1.5 $\mathrm{IC}_{50}$ of $0.15 \mu \mathrm{M}$ and $h \mathrm{ERG}$ with an $\mathrm{IC}_{50}$ value $>10 \mu \mathrm{M}$. Furthermore, favorable pharmacokinetic properties in rats and dogs of $\mathbf{8 0}$ were determined; compound $\mathbf{8 0}$ was identified with less than $1 \%$ GSH adducts formation with an improved PK profile and equivalent PD efficacy to the lead compound (Figure 20).

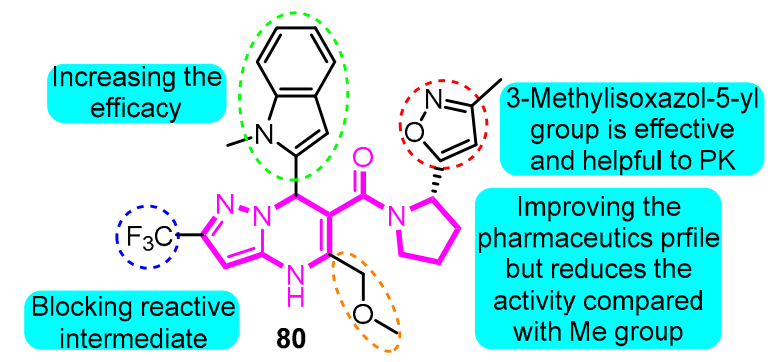

Figure 20. SAR of dihydropyrazolo[1,5-a]pyrimidine derivatives.

In 2013, triazolo and imidazo were introduced into the active scaffold dihydropyrazolopyrimidine [96]. Trifluoromethylcyclohexyl triazole analogue $\mathbf{8 1}$ was identified as a potent and selective $\mathrm{Kv} 1.5$ inhibitor $\left(\mathrm{IC}_{50}: 133 \mathrm{nM}\right)$ with an acceptable PK and liability profile. Compound $\mathbf{8 1}$ demonstrated an improved rat PK profile and was advanced to the rat PD model (Figure 21). 


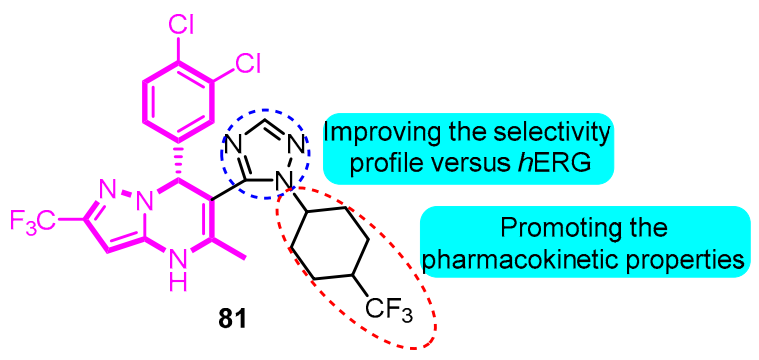

Figure 21. SAR of trifluoromethylcyclohexyl triazole analogues.

With the help of a pharmacophore model, Guo et al. [97] designed and synthesized a series of indole derivatives as potent Kv1.5 inhibitors. The most promising compound $\mathbf{8 2}$ displayed significant $I_{\mathrm{Na}}$, HEK $293 \mathrm{hKv} 1.5$, and CHO $h$ ERG inhibitory activities with $\mathrm{IC}_{50}$ values of 52.6, 0.51, and $418.35 \mu \mathrm{M}$, respectively, which displayed remarkable selectivity and ameliorating effects on atrial effective refractory period (AERP) and VERP (Figure 22).

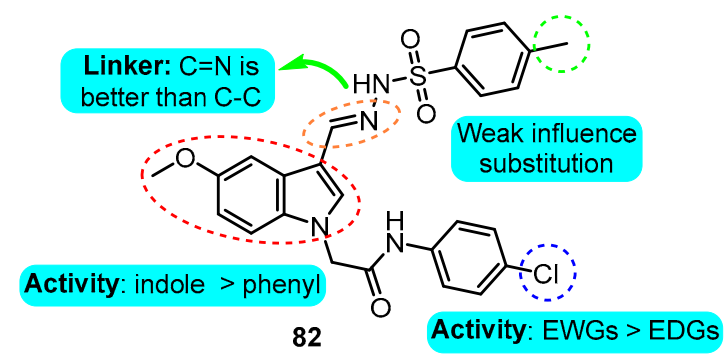

Figure 22. SAR of indole derivatives.

Olsson and co-workers [98] possessed design and pharmacological evaluation of multiple potential hits targeting on $\mathrm{Kv} 1.5$. The compound 83 performed the best in vitro activity with $\mathrm{Kv} 1.5 \mathrm{IC}_{50}$ of $0.08 \mu \mathrm{M}$ in diphenylphosphinic amide and diphenylphosphine oxide analogues (Figure 23). However, both $h$ ERG and IKs active and remarkable safety in rats of compound $\mathbf{8 3}$ was detected and judged unsuitable for in vivo testing; conversely, the derivative $\mathbf{8 4}$ was regarded as a hopeful compound for further development with $\mathrm{Kv}_{1.5} \mathrm{IC}_{50}, \mathrm{IKs}_{2} \mathrm{C}_{\mathrm{eu} 20}$, and $\mathrm{QT}_{\max }$ change values for $1.0 \mu \mathrm{M},>33 \%, 0.6 \mu \mathrm{M}$, and $<10 \%$, respectively.

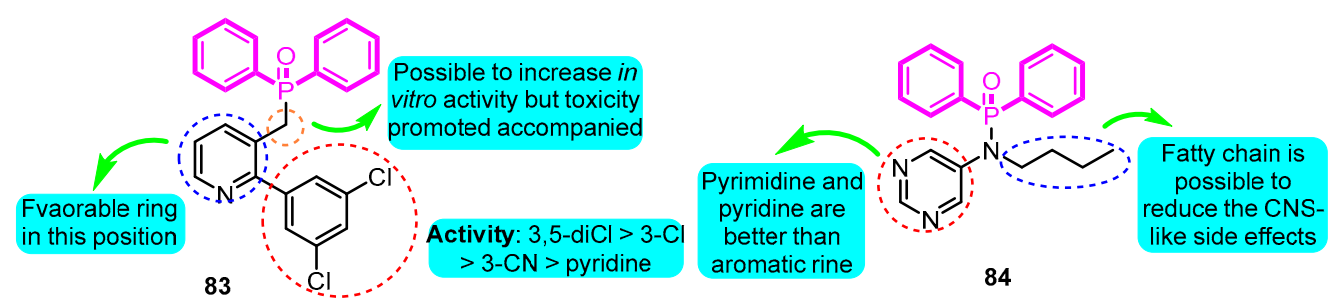

Figure 23. SAR of diphenylphosphinic amides and diphenylphosphine oxides.

In 2014, the subsequent study was updated [99], and a series of lactam sulfonamide derivatives was prepared and the Kv1.5 inhibitory potency was evaluated. The most promising candidate 85 inhibited $\mathrm{Kv} 1.5$ with an $\mathrm{IC}_{50}$ value of $0.21 \mu \mathrm{M}$ and caused a marked increase in the atrium ERP with a $\mathrm{C}_{\text {eu20 }}$ of $0.35 \mu \mathrm{M}$, which was at the same order of magnitude as the $\mathrm{IC}_{50}$ value from the human cellular assay. The human $h$ ERG channel was blocked by compound 85 with an $\mathrm{IC}_{50}$ value of $30 \mu \mathrm{M}$, indicating a 140 fold margin of the $h$ ERG and Kv1.5 in vitro values. No measurable change was noted in the QT-interval in the rabbit experiments, which also indicated a good margin to block of the $h$ ERG channel. The compound $\mathbf{8 5}$ was well tolerated in rabbits with no signs of the CNS-like side effects observed for other Kv1.5 blockers (Figure 24). 


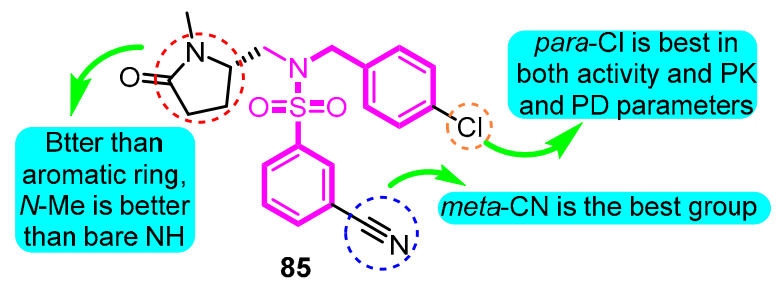

Figure 24. SAR of lactam sulfonamides.

Johnson et al. [100] synthesized phenethylaminoheterocycles and assayed for inhibition of the Kv1.5 potassium ion channel as a potential approach to the treatment of atrial fibrillation. Combination of the indazole with a cyclohexane-based template gave the most promising derivative $86\left(\mathrm{Kv} 1.5 \mathrm{IC}_{50}\right.$ : $138 \mathrm{nM}$ ) which demonstrated significant prolongation of AERP in the rabbit pharmacodynamic model (Figure 25).

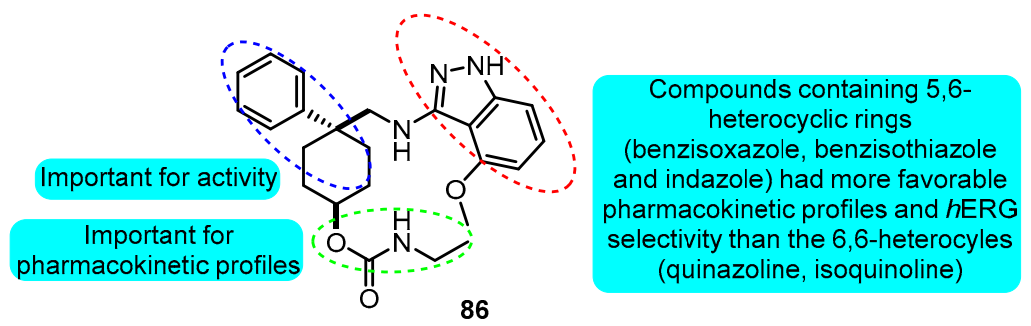

Figure 25. SAR of phenethylaminoheterocycles.

Guo and colleagues [101] prepared a series of 1-aryloxyethyl piperazine derivatives as Kv1.5 potassium channel inhibitors. The most potent compound 87 exerted significant activity on $h \mathrm{Kv} 1.5$ (IC $\mathrm{I}_{50}: 0.72 \mu \mathrm{M}$ ), balanced $\log \mathrm{D}$, and permeability. In addition, comparable in vivo potency with sotalol and dronedarone and remarkable safety in rats of compound 87 were detected as well (Figure 26).

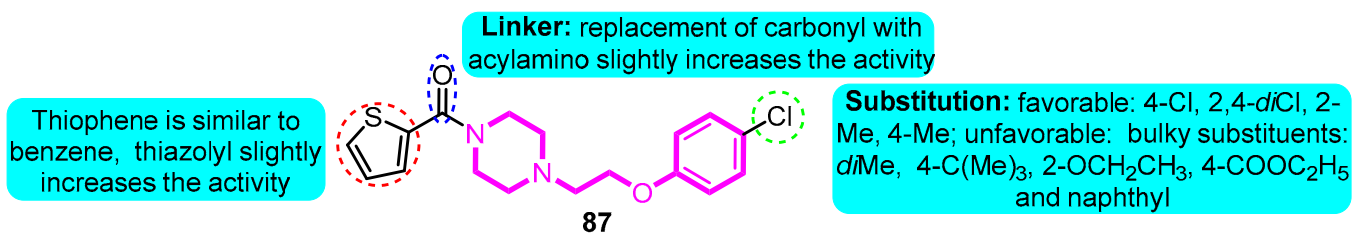

Figure 26. SAR of 1-aryloxyethyl piperazine derivatives.

In 2016, Kajanus et al. [102] synthesized multiple isoindolinone compounds as Kv1.5 blockers. The most potent compounds $\mathbf{8 8}$ and $\mathbf{8 9}$ exhibited an inhibitory effect with the $\mathrm{IC}_{50}$ values of 0.4 and $0.7 \mu \mathrm{M}$ on Kv1.5, respectively. The above-mentioned two compounds were found to have desirable in vivo PK properties in a mouse model (Figure 27).

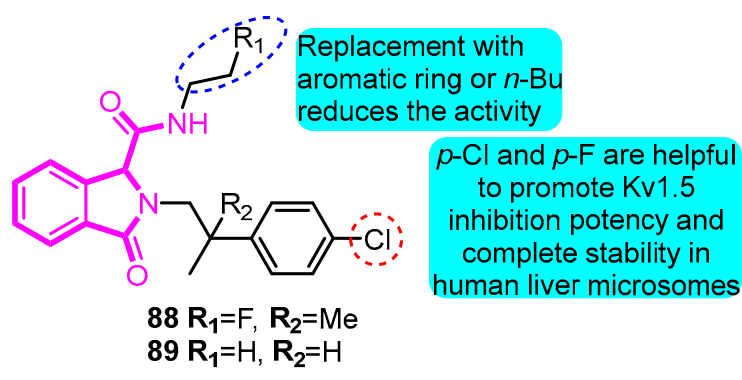

Figure 27. SAR of isoindolinones. 
Finlay and co-workers [103] explored phenylquinazoline derivatives as Kv1.5 inhibitors. 5-Phenyl- $N$-(pyridin-2-ylmethyl)-2-(pyrimidin-5-yl)quinazolin-4-amine (90) was identified as a potent and ion channel selective inhibitor (Kv1.5 IC 50 : $90 \mathrm{nM}, h$ ERG inhibition: $43 \%$ at $10 \mu \mathrm{M}$ ) with robust efficacy in the pre-clinical rat ventricular effective refractory period (VERP) model and the rabbit atrial effective refractory period (AERP) model (Figure 28).

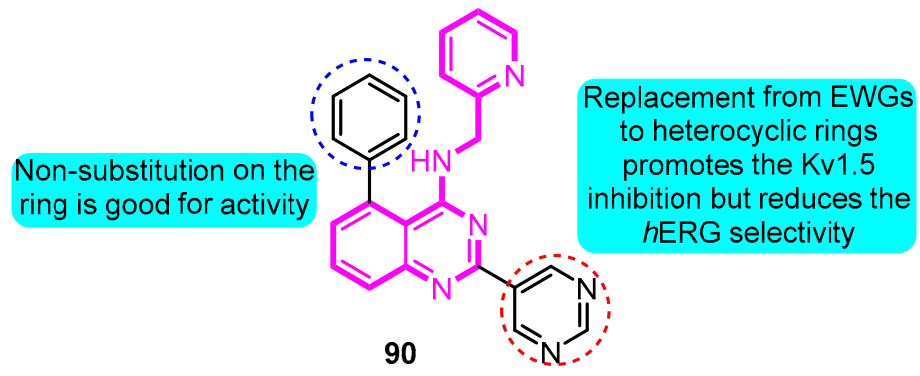

Figure 28. SAR of phenylquinazoline derivatives.

Subsequently in 2017, Gunaga et al. [58] modified the structure of 91 with a series of analogues and evaluated the $I_{\text {Kur }}$ inhibitory effect. 5-[5-Phenyl-4-(pyridin-2-ylmethylamino)-quinazolin-2-yl] pyridine-3-sulfonamide (92) was identified as the lead compound in this series with good selectivity over $h \mathrm{ERG}\left(\mathrm{Kv} 1.5 \mathrm{IC}_{50}: 50 \mathrm{nM}, h \mathrm{ERG} \mathrm{IC}_{50}: 1.9 \mu \mathrm{M}\right)$. Compound 91 exhibited robust effects in rabbit and canine pharmacodynamic models and an acceptable cross-species pharmacokinetic profile which was then advanced as a clinical candidate. Further optimization of $\mathbf{9 1}$ to mitigate $\mathrm{pH}$-dependent absorption resulted in identification of the corresponding phosphoramide prodrug $(\mathbf{9 2})$ with an improved solubility and pharmacokinetic profile (Figure 29).

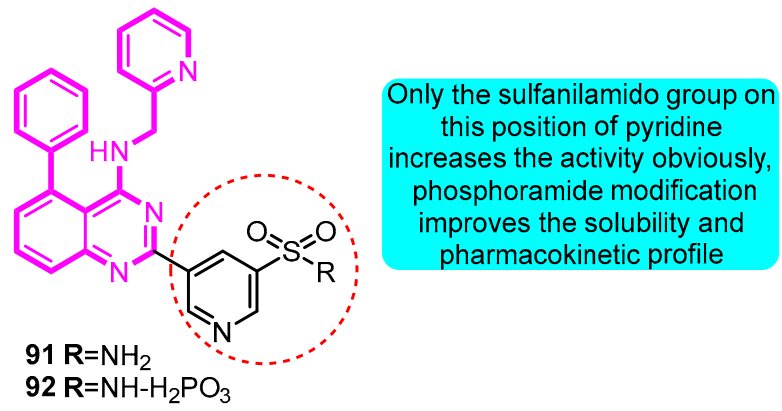

Figure 29. SAR of phenylquinazoline sulfonamide derivatives.

According to the skeleton of Agelas alkaloids clathrodin, oroidin, and hymenidin, Zidar and colleagues [104] synthesized multiple derivatives as inhibitors of the voltage-gated potassium channels. The most potent inhibitor was (E)-N-(3-(2-amino-1H-imidazol-4-yl)allyl)-4, 5-dichloro-1H-pyrrole-2-carboxamide (93) with $\mathrm{IC}_{50}$ values between 1.4 and $6.1 \mathrm{mM}$ against $\mathrm{Kv} 1.3$, Kv1.4, Kv1.5, and Kv1.6 channels (Kv1.5 IC $50: 6.1 \mu \mathrm{M})$ (Figure 30).

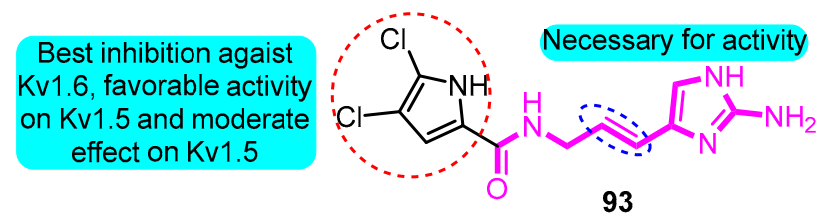

Figure 30. SAR of oroidin derivatives.

Wolkenberg et al. [105] told the story of the development of prospective candidate MK-1832 (94) (Figure 31). Based on the structure of MK-0448, a cluster of derivatives were synthesized and tested 
the Kv1.5 inhibitory effect and in vivo and in vitro toxicity. MK-1832 (94) was considered to be the best derivative with pharmacological parameters including Kv1.5, $\mathrm{I}_{\mathrm{kur}}$, and $\mathrm{I}_{\mathrm{kr}}(h \mathrm{ERG}) \mathrm{IC}_{50}$ values for 29,11 and $1.28 \times 10^{5} \mathrm{nM}$, respectively, and pharmacokinetic parameters including dog in vivo atrial refractory period $\mathrm{EC}_{10}$ for $14 \mathrm{nM}$ and threshold change in ventricular refractory period $>25 \mu \mathrm{M}$.

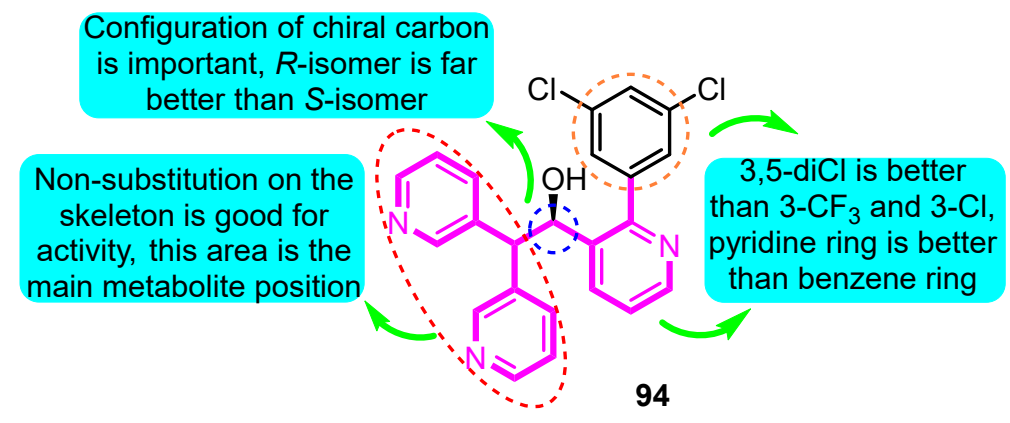

Figure 31. SAR of oroidin MK-1832.

In 2019, Kajanus and colleagues [106] prepared potassium channel blocking 1,2-bis(aryl)ethane-1, 2-diamines active as antiarrhythmic agents. The most promising analogue 95 displayed significant nanomolar potency in blocking Kv1.5 in human atrial myocytes $\left(\mathrm{IC}_{50}: 1.7 \mu \mathrm{M}, I_{\mathrm{Kur}} \mathrm{IC}_{50}: 60 \mathrm{nM}\right)$ and based on the PD data, the estimated dose for men was $700 \mathrm{mg} /$ day (Figure 32).

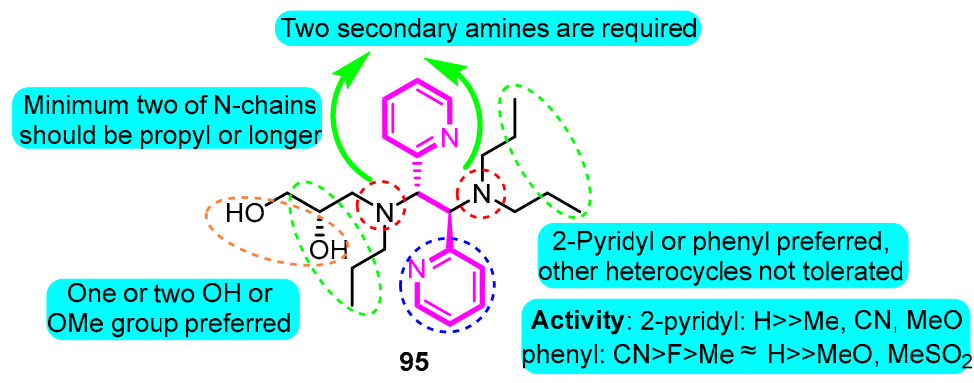

Figure 32. SAR of 1,2-bis(aryl)ethane-1,2-diamines.

Recently, natural products with novel structural motif as a Kv1.5 inhibitor also gained progress in this field. In the sequence of the isolation of compound debromoaplysiatoxin A (38) and debromoaplysiatoxin B (39) [63], Tang and co-workers [14] identified other novel aplysiatoxin derivatives from the marine cyanobacterium Lyngbya sp. Among them, compound oscillatoxin E (96) with the hexane-tetrahydropyran of a spirobicyclic system skeleton exhibited the strongest Kv1.5 inhibition $\left(\mathrm{IC}_{50}: 0.79 \mu \mathrm{M}\right)$ in the $\mathrm{CHO}$ cells at an $\mathrm{HP}$ of $-80 \mathrm{mV}$ (Figure 33).

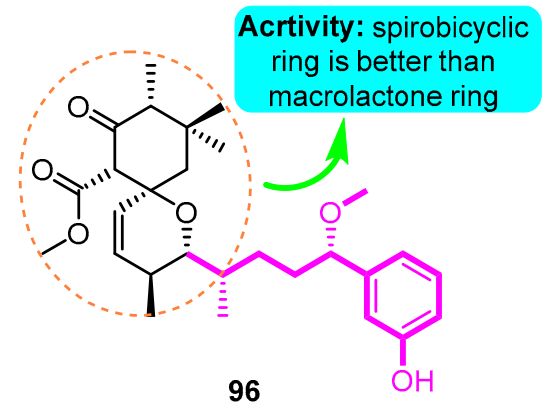

Figure 33. SAR of aplysiatoxin derivatives. 


\section{Conclusions}

Herein the target and the pharmacological properties with structural, pharmacological, and SAR information of Kv1.5 modulators were discussed. Detailed descriptions of pharmacology parameters and SAR studies provide an actionable path forward for medicinal chemists to optimize the structure of Kv1.5 modulators. Further experiments should improve the PK and safety after the effectiveness is proven. Design and development of potential and selective Kv1.5 modulators are important and challenging tasks. Based on the existing pharmacophoric requirements and potential protein structure parsed in the future, some novel effective Kv1.5 modulators may be designed and prepared [107,108]. However, gaps exist in the scientific studies on Kv1.5 modulators. Firstly, the selectivity of existing Kv1.5 modulators remains to be investigated, and more specific modulators aiming at the Kv1.5 channel are needed in the future. Secondly, from the point of application, the market of AF is relatively small, and the sales condition of marked anti-AF agents is not satisfactory as a whole, thus more in-depth pharmacological investigation of roles of Kv1.5 are required in the future. Moreover, the definite structure of Kv1.5 protein is still vacant, difficulties and potential fallacy are still consistent in the design of modulators only estimating by the pocket of homologous models.

SAR investigation is crucial for the development of novel promising clinical candidates. It is anticipated that the information compiled in this review article not only updates researchers with the recently reported pharmacology and SAR of Kv1.5 modulators, but also motivates them to design and synthesize promising Kv1.5 modulators with improved medicinal properties.

Funding: This work was supported by the Changiiang Scholars and Innovative Research Team in Universities, Ministry of Education of China (IRT_15R55), the 9th Group of Hundred Talent Program of Shaanxi Province (2017), Biomedicine Key Laboratory of Shaanxi Province (No. 2018SZS41), and the International Science and Technology Cooperation Program of Shaanxi Province (No. 2019KWZ-001).

Conflicts of Interest: The authors declare no conflict of interest.

\section{Abbreviations}

$\begin{array}{ll}\text { AF } & \text { Atrial fibrillation } \\ \text { BLAST } & \text { Basic Local Alignment Search Tool } \\ \text { C }_{\text {eu20 }} & \text { Unbound steady-state plasma concentration } \\ \text { CHO cells } & \text { Chinese hamster ovary cells } \\ \text { CNS } & \text { Central nervous system } \\ \text { EDGs } & \text { Electron donating groups } \\ \text { EWGs } & \text { Electron withdrawing groups } \\ \text { HEK cells } & \text { Human embryonic kidney 293 cells } \\ h \text { ERG } & \text { Human ether-à-go-go-related gene } \\ h \text { Kv1.5 channels } & \text { Human Kv1.5 channels } \\ \text { Human PASMCs } & \text { Human pulmonary arterial smooth muscle cells } \\ I_{\text {Kur }} & \text { Cardiac ultra-rapid delayed-rectifier } \\ \text { IC } 50 & \text { 50\% inhibitory concentration } \\ \text { Ile } & \text { Isoleucine } \\ \text { Nrf2 } & \text { Nuclear factor erythroid 2-related factor } \\ \text { SAR } & \text { Structure-activity relationship } \\ \text { Thr } & \text { Threonine } \\ \text { Val } & \text { Valine } \\ \text { VERP } & \text { Ventricular effective refractory period }\end{array}$

\section{References}

1. Milnes, J.T.; Madge, D.J.; Ford, J.W. New pharmacological approaches to atrial fibrillation. Drug Discov. Today 2012, 17, 654-659. [CrossRef] [PubMed]

2. Amos, G.J.; Wettwer, E.; Metzger, F.; Li, Q.; Himmel, H.M.; Ravens, U. Differences between outward currents of human atrial, and subepicardial ventricular myocytes. J. Physiol. 1996, 491, 31-50. [CrossRef] [PubMed] 
3. Humphries, E.S.A.; Dart, C. Neuronal and cardiovascular potassium channels as therapeutic drug targets: Promise and pitfalls. J. Biomol. Screen. 2015, 20, 1055-1073. [CrossRef] [PubMed]

4. Kojima, A.; Ito, Y.; Ding, W.-G.; Kitagawa, H.; Matsuura, H. Interaction of propofol with voltage-gated human Kv1.5 channel through specific amino acids within the pore region. Eur. J. Pharmacol. 2015, 764, 622-632. [CrossRef] [PubMed]

5. Nerbonne, J.M.; Kass, R.S. Molecular physiology of cardiac repolarization. Physiol. Rev. 2005, 85, 1205-1253. [CrossRef]

6. Tamargo, J.; Caballero, R.; Gomez, R.; Delpon, E. I-Kur/Kv1.5 channel blockers for the treatment of atrial fibrillation. Expert Opin. Inv. Drug. 2009, 18, 399-416. [CrossRef]

7. Yellen, G. The voltage-gated potassium channels and their relatives. Nature 2002, 419, 35-42. [CrossRef]

8. Tikhonov, D.B.; Zhorov, B.S. Homology modeling of Kv1.5 channel block by cationic and electroneutral ligands. Biochim. Biophys. Acta. 2014, 1838, 978-987. [CrossRef]

9. Wu, J.; Ding, W.G.; Matsuura, H.; Tsuji, K.; Zang, W.J.; Horie, M. Inhibitory actions of the phosphatidylinositol 3-kinase inhibitor LY294002 on the human Kv1.5 channel. Brit. J. Pharmacol. 2009, 156, 377-387. [CrossRef]

10. Guex, N.; Peitsch, M.C.; Schwede, T. Automated comparative protein structure modeling with SWISS-MODEL and Swiss-PdbViewer: A historical perspective. Electrophoresis 2009, 30, S162-S173. [CrossRef]

11. Chen, R.; Chung, S.-H. Inhibition of Voltage-Gated $\mathrm{K}^{+}$Channel Kv1.5 by Antiarrhythmic Drugs. Biochemistry 2018, 57, 2704-2710. [CrossRef] [PubMed]

12. Altschul, S.F.; Madden, T.L.; Schaffer, A.A.; Zhang, J.; Zhang, Z.; Miller, W.; Lipman, D.J. Gapped BLAST and PSI-BLAST: A new generation of protein database search programs. Nucleic Acids Res. 1997, 25, 3389-3402. [CrossRef]

13. Robert, X.; Gouet, P. Deciphering key features in protein structures with the new ENDscript server. Nucleic Acids Res. 2014, 42, W320-W324. [CrossRef] [PubMed]

14. Tang, Y.H.; Wu, J.; Fan, T.T.; Zhang, H.H.; Gong, X.X.; Cao, Z.Y.; Zhang, J.; Lin, H.W.; Han, B.N. Chemical and biological study of aplysiatoxin derivatives showing inhibition of potassium channel Kv1.5. RSC Adv. 2019, 9, 7594-7600. [CrossRef]

15. Li, K.; Cheng, N.; Li, X.T. Inhibitory effects of cholinesterase inhibitor donepezil on the Kv1.5 potassium channel. Sci. Rep. 2017, 7, 41509-41518. [CrossRef] [PubMed]

16. Chen, X.; Xue, B.; Wang, J.; Liu, H.; Shi, L.; Xie, J. Potassium channels: A potential therapeutic target for Parkinson's disease. Neurosci. Bull. 2018, 34, 341-348. [CrossRef] [PubMed]

17. Li, P.; Chen, Z.; Xu, H.; Sun, H.; Li, H.; Liu, H.; Yang, H.; Gao, Z.; Jiang, H.; Li, M. The gating charge pathway of an epilepsy-associated potassium channel accommodates chemical ligands. Cell Res. 2013, 23, 1106-1118. [CrossRef] [PubMed]

18. Seifert, G.; Henneberger, C.; Steinhaeuser, C. Diversity of astrocyte potassium channels: An update. Brain Res. Bull. 2018, 136, 26-36. [CrossRef]

19. Schmitt, N.; Grunnet, M.; Olesen, S.P. Cardiac potassium channel subtypes: New roles in repolarization and arrhythmia. Physiol. Rev. 2014, 94, 609-653. [CrossRef]

20. Geller, J.C.; Egstrup, K.; Kulakowski, P.; Rosenqvist, M.; Jansson, M.A.; Berggren, A.; Edvardsson, N.; Sager, P.; Crijns, H.J. Rapid conversion of persistent atrial fibrillation to sinus rhythm by intravenous AZD7009. J. Clin. Pharmacol. 2009, 49, 312-322. [CrossRef]

21. Ng, F.L.; Davis, A.J.; Jepps, T.A.; Harhun, M.I.; Yeung, S.Y.; Wan, A.; Reddy, M.; Melville, D.; Nardi, A.; Khong, T.K.; et al. Expression and function of the K plus channel KCNQ genes in human arteries. Br. J. Pharmacol. 2011, 162, 42-53. [CrossRef] [PubMed]

22. Barros, F.; Pardo, L.A.; Dominguez, P.; Maria Sierra, L.; De la Pena, P. New Structures and Gating of Voltage-Dependent Potassium (Kv) Channels and Their Relatives: A Multi-Domain and Dynamic Question. Int. J. Mol. Sci. 2019, 20, 248. [CrossRef] [PubMed]

23. Mozrzymas, J.W.; Teisseyre, A.; Vittur, F. Propofol blocks voltage-gated potassium channels in human T lymphocytes. Biochem. Pharmacol. 1996, 52, 843-849. [CrossRef]

24. Teisseyre, A.; Michalak, K. Inhibition of the activity of human lymphocyte Kv1.3 potassium channels by resveratrol. J. Membr. Biol. 2006, 214, 123-129. [CrossRef]

25. Ishii, T.; Warabi, E.; Siow, R.C.M.; Mann, G.E. Sequestosome1/p62: A regulator of redox-sensitive voltage-activated potassium channels, arterial remodeling, inflammation, and neurite outgrowth. Free Radic. Biol. Med. 2013, 65, 102-116. [CrossRef] 
26. Dos Santos-Nascimento, T.; Veras, K.M.; Cruz, J.S.; Leal-Cardoso, J.H. Inhibitory Effect of Terpinen-4-ol on Voltage-Dependent Potassium Currents in Rat Small Sensory Neurons. J. Nat. Prod. 2015, 78, 173-180. [CrossRef]

27. Kulcitki, V.; Harghel, P.; Ungur, N. Unusual cyclic terpenoids with terminal pendant prenyl moieties: From occurrence to synthesis. Nat. Prod. Rep. 2014, 31, 1686-1720. [CrossRef]

28. Menezes, P.M.N.; Brito, M.C.; de Paiva, G.O.; dos Santos, C.O.; de Oliveira, L.M.; Ribeiro, L.A.D.; De Lima, J.T.; Lucchese, A.M.; Silva, F.S. Relaxant effect of Lippia origanoides essential oil in guinea-pig trachea smooth muscle involves potassium channels and soluble guanylyl cyclase. J. Ethnopharmacol. 2018, 220, 16-25. [CrossRef]

29. Kalyaanamoorthy, S.; Barakat, K.H. Development of safe crugs: The $h$ ERG challenge. Med. Res. Rev. 2018, 38, 525-555. [CrossRef]

30. Cheong, A.; Dedman, A.M.; Beech, D.J. Expression and function of native potassium channel (K-v alpha 1) subunits in terminal arterioles of rabbit. J. Physiol. 2001, 534, 691-700. [CrossRef]

31. Xie, Y.; Ding, W.; Liu, Y.; Yu, M.; Sun, X.; Matsuura, H. Long-term 4-AP treatment facilitates functional expression of human Kv1.5 channel. Eur. J. Pharmacol. 2019, 844, 195-203. [CrossRef] [PubMed]

32. Eldstrom, J.; Wang, Z.; Xu, H.; Pourrier, M.; Ezrin, A.; Gibson, K.; Fedida, D. The molecular basis of high-affinity binding of the antiarrhythmic compound vernakalant (RSD1235) to Kv1.5 channels. Mol. Pharmacol. 2007, 72, 1522-1534. [CrossRef] [PubMed]

33. Kodama, I.; Kamiya, K.; Honjo, H.; Toyama, J. Acute and chronic effects of amiodarone on mammalian ventricular cells. Jpn. Heart J. 1996, 37, 719-730. [CrossRef] [PubMed]

34. Herrera, D.; Mamarbachi, A.; Simoes, M.; Parent, L.; Sauve, R.; Wang, Z.G.; Nattel, S. A single residue in the S6 transmembrane domain governs the differential flecainide sensitivity of voltage-gated potassium channels. Mol. Pharmacol. 2005, 68, 305-316. [CrossRef]

35. Lin, S.; Wang, Z.; Fedida, D. Influence of permeating ions on Kv1.5 channel block by nifedipine. Am. J. Physiol. Heart Circ. Physiol. 2001, 280, H1160-H1172. [CrossRef]

36. Franqueza, L.; Valenzuela, C.; Delpon, E.; Longobardo, M.; Caballero, R.; Tamargo, J. Effects of propafenone and 5-hydroxy-propafenone on $h \mathrm{Kv} 1.5$ channels. Brit. J. Pharmacol. 1998, 125, 969-978. [CrossRef]

37. Fedida, D. Gating charge and ionic currents associated with quinidine block of human Kv1.5 delayed rectifier channels. J. Physiol. 1997, 499, 661-675. [CrossRef]

38. Caballero, R.; Gomez, R.; Nunez, L.; Moreno, I.; Tamargo, J.; Delpon, E. Diltiazem inhibits $h$ Kv1.5 and Kv4.3 currents at therapeutic concentrations. Cardiovasc. Res. 2004, 64, 457-466. [CrossRef]

39. Chow, L.W.C.; Cheng, K.-S.; Wong, K.-L.; Leung, Y.-M. Voltage-gated K+ channels promote BT-474 breast cancer cell migration. Chin. J. Cancer Res. 2018, 30, 613-622. [CrossRef]

40. Malayev, A.A.; Nelson, D.J.; Philipson, L.H. Mechanism of clofilium block of the human Kv1.5 delayed rectifier potassium channel. Mol. Pharmacol. 1995, 47, 198-205.

41. Yang, I.C.H.; Scherz, M.W.; Bahinski, A.; Bennett, P.B.; Murray, K.T. Stereoselective interactions of the enantiomers of chromanol 293B with human voltage-gated potassium channels. J. Pharmacol. Exp. 2000, 294, 955-962.

42. Kobayashi, S.; Reien, Y.; Ogura, T.; Saito, T.; Masuda, Y.; Nakaya, H. Inhibitory effect of bepridil on $h \mathrm{Kv} 1.5$ channel current: Comparison with amiodarone and E-4031. Eur. J. Pharmacol. 2001, 430, 149-157. [CrossRef]

43. Lee, H.M.; Hahn, S.J.; Choi, B.H. Blockade of Kv1.5 by paroxetine, an antidepressant drug. Korean J. Physiol. Pharmacol. 2016, 20, 75-82. [CrossRef] [PubMed]

44. Dai, F.F.; Mao, Z.F.; Xia, J.; Zhu, S.P.; Wu, Z.Y. Fluoxetine protects against big endothelin-1 induced anti-apoptosis by rescuing Kv1.5 channels in human pulmonary arterial smooth muscle cells. Yonsei Med. J. 2012, 53, 842-848. [CrossRef] [PubMed]

45. Lee, H.M.; Hahn, S.J.; Choi, B.H. Blockade of Kv1.5 channels by the antidepressant drug sertraline. Korean J. Physiol. Pharmacol. 2016, 20, 193-200. [CrossRef] [PubMed]

46. Yu, J.; Park, M.-H.; Jo, S.-H. Inhibitory effects of cortisone and hydrocortisone on human Kv1.5 channel currents. Eur. J. Pharmacol. 2015, 746, 158-166. [CrossRef]

47. Lammers, C.; Dartsch, T.; Brandt, M.C.; Rottlander, D.; Halbach, M.; Peinkofer, G.; Ockenpoehler, S.; Weiergraeber, M.; Schneider, T.; Reuter, H.; et al. Spironolactone prevents aldosterone induced increased duration of atrial fibrillation in rat. Cell Physiol. Biochem. 2012, 29, 833-840. [CrossRef] 
48. Frolov, R.V.; Singh, S. Celecoxib and ion channels: A story of unexpected discoveries. Eur. J. Pharmacol. 2014, 730, 61-71. [CrossRef]

49. Luzhkov, V.B.; Nilsson, J.; Arhem, P.; Aqvist, J. Computational modelling of the open-state K(v)1.5 ion channel block by bupivacaine. Biochim. Biophys. Acta. 2003, 1652, 35-51. [CrossRef]

50. Valenzuela, C.; Delpon, E.; Tamkun, M.M.; Tamargo, J.; Snyders, D.J. Stereoselective block of a human cardiac potassium channel (Kv1.5) by bupivacaine enantiomers. Biophys. J. 1995, 69, 418-427. [CrossRef]

51. Vonderlin, N.; Fischer, F.; Zitron, E.; Seyler, C.; Scherer, D.; Thomas, D.; Katus, H.A.; Scholz, E.P. Inhibition of cardiac Kv1.5 potassium current by the anesthetic midazolam: Mode of action. Drug Des. Dev. 2014, 8 , 2263-2271.

52. Su, J.P.; Huang, Y.; Lenka, N.; Hescheler, J.; Ullrich, S. The expression and regulation of depolarization-activated $\mathrm{K}+$ channels in the insulin-secreting cell line INS-1. Pflugers Arch. 2001, 442, 49-56. [CrossRef] [PubMed]

53. Caballero, R.; Moreno, I.; Gonzalez, T.; Valenzuela, C.; Tamargo, J.; Delpon, E. Putative binding sites for benzocaine on a human cardiac cloned channel (Kv1.5). Cardiovasc. Res. 2002, 56, 104-117. [CrossRef]

54. Jie, L.; Wu, W.; Li, G.; Xiao, G.; Zhang, S.; Li, G.; Wang, Y. Clemizole hydrochloride blocks cardiac potassium currents stably expressed in HEK 293 cells. Brit. J. Pharmacol. 2017, 174, 254-266. [CrossRef] [PubMed]

55. Wirth, K.J.; Brendel, J.; Steinmeyer, K.; Linz, D.K.; Ruetten, H.; Goegelein, H. In vitro and in vivo effects of the atrial selective antiarrhythmic compound AVE1231. J. Cardiovasc. Pharmacol. 2007, 49, 197-206. [CrossRef]

56. Persson, F.; Carlsson, L.; Duke, G.; Jacobson, I. Blocking characteristics of hKv1.5 and hKv4.3/hKChIP2.2 after administration of the novel antiarrhythmic compound AZD7009. J. Cardiovasc. Pharmacol. 2005, 46, 7-17. [CrossRef]

57. Lloyd, J.; Finlay, H.J.; Vacarro, W.; Hyunh, T.; Kover, A.; Bhandaru, R.; Yan, L.; Atwal, K.; Conder, M.L.; Jenkins-West, T.; et al. Pyrrolidine amides of pyrazolodihydropyrimidines as potent and selective KV1.5 blockers. Bioorg. Med. Chem. Lett. 2010, 20, 1436-1439. [CrossRef]

58. Gunaga, P.; Lloyd, J.; Mummadi, S.; Banerjee, A.; Dhondi, N.K.; Hennan, J.; Subray, V.; Jayaram, R.; Rajugowda, N.; Reddy, K.U.; et al. Selective I-Kur inhibitors for the potential treatment of atrial fibrillation: Optimization of the phenyl quinazoline series leading to clinical candidate 55-phenyl-4-(pyridin-2-ylmethylamino)quinazolin-2-yl pyridine-3-sulfon amide. J. Med. Chem. 2017, 60, 3795-3803. [CrossRef]

59. Loose, S.; Mueller, J.; Wettwer, E.; Knaut, M.; Ford, J.; Milnes, J.; Ravens, U. Effects of $I_{\text {Kur }}$ blocker MK-0448 on human right atrial action potentials from patients in sinus rhythm and in permanent atrial fibrillation. Front. Pharmacol. 2014, 5, 26-32. [CrossRef]

60. Ford, J.; Milnes, J.; El Haou, S.; Wettwer, E.; Loose, S.; Matschke, K.; Tyl, B.; Round, P.; Ravens, U. The positive frequency-dependent electrophysiological effects of the $I_{\text {Kur }}$ inhibitor XEN-D0103 are desirable for the treatment of atrial fibrillation. Heart Rhythm 2016, 13, 555-564. [CrossRef]

61. Gautier, P.; Guillemare, E.; Djandjighian, L.; Marion, A.; Planchenault, J.; Bernhart, C.; Herbert, J.M.; Nisato, D. In vivo and in vitro characterization of the novel antiarrhythmic agent SSR149744C-Electrophysiological, anti-adrenergic, and anti-angiotensin II effects. J. Cardiovasc. Pharmacol. 2004, 44, 244-257. [CrossRef] [PubMed]

62. Gasparoli, L.; D’Amico, M.; Masselli, M.; Pillozzi, S.; Caves, R.; Khuwaileh, R.; Tiedke, W.; Mugridge, K.; Pratesi, A.; Mitcheson, J.S.; et al. New pyrimido-indole compound CD-160130 preferentially inhibits the $\mathrm{K}(\mathrm{V}) 11.1 \mathrm{~B}$ isoform and produces antileukemic effects without cardiotoxicity. Mol. Pharmacol. 2015, 87, 183-196. [CrossRef] [PubMed]

63. Han, B.; Liang, T.; Keen, L.J.; Fan, T.; Zhang, X.; Xu, L.; Zhao, Q.; Wang, S.; Lin, H. Two marine cyanobacterial aplysiatoxin polyketides, neo-debromoaplysiatoxin $\mathrm{A}$ and $\mathrm{B}$, with $\mathrm{K}^{+}$channel inhibition activity. Org. Lett. 2018, 20, 578-581. [CrossRef] [PubMed]

64. Grissmer, S.; Nguyen, A.N.; Aiyar, J.; Hanson, D.C.; Mather, R.J.; Gutman, G.A.; Karmilowicz, M.J.; Auperin, D.D.; Chandy, K.G. Pharmacological characterization of five cloned voltage-gated K+ channels, types Kv1.1, 1.2, 1.3, 1.5, and 3.1, stably expressed in mammalian cell lines. Mol. Pharmacol. 1994, 45, 1227-1234. [PubMed]

65. Kwak, Y.G.; Kim, D.K.; Ma, T.; Park, S.-A.; Park, H.; Jung, Y.H.; Yoo, D.-J.; Eun, J.S. Torilin from Torilis japonica (Houtt.) DC. blocks $h \mathrm{Kv} 1.5$ channel current. Arch. Pharmacol. Res. 2006, 29, 834-839. [CrossRef] 
66. Jin, S.; Guo, Q.; Xu, J.; Yu, P.; Liu, J.; Tang, Y. Antiarrhythmic ionic mechanism of Guanfu base A -Selective inhibition of late sodium current in isolated ventricular myocytes from guinea pigs. Chin. J. Nat. Med. 2015, 13, 361-367. [CrossRef]

67. Jeong, I.; Choi, B.H.; Hahn, S.J. Effects of lobeline, a nicotinic receptor ligand, on the cloned Kv1.5. Pflugers Arch. 2010, 460, 851-862. [CrossRef]

68. Fischer, F.; Vonderlin, N.; Zitron, E.; Seyler, C.; Scherer, D.; Becker, R.; Katus, H.A.; Scholz, E.P. Inhibition of cardiac Kv1.5 and Kv4.3 potassium channels by the class Ia anti-arrhythmic ajmaline: Mode of action. Naunyn Schmiedebergs Arch. Pharmacol. 2013, 386, 991-999.

69. Choe, H.; Lee, Y.K.; Lee, Y.T.; Choe, H.; Ko, S.H.; Joo, C.U.; Kim, M.H.; Kim, G.S.; Eun, J.S.; Kim, J.H.; et al. Papaverine blocks hKv1.5 channel current and human atrial ultrarapid delayed rectifier $\mathrm{K}^{+}$currents. Can. J. Cardiol. 2003, 304, 706-712. [CrossRef]

70. Li, K.; Pi, M.; Li, X. The inhibitory effects of levo-tetrahydropalmatine on rat Kv1.5 channels expressed in HEK293 cells. Eur. J. Pharmacol. 2017, 809, 105-110. [CrossRef]

71. Li, Y.F.; Tu, D.N.; Xiao, H.; Du, Y.M.; Zou, A.R.; Liao, Y.H.; Dong, S.H. Aconitine blocks HERG and Kv1.5 potassium channels. J. Ethnopharmacol. 2010, 131, 187-195. [CrossRef] [PubMed]

72. Ou, X.; Bin, X.; Wang, L.; Li, M.; Yang, Y.; Fan, X.; Zeng, X. Myricetin inhibits K (v) 1.5 channels in HEK293 cells. Mol. Med. Rep. 2016, 13, 1725-1731. [CrossRef]

73. Liu, Y.; Xu, X.; Liu, Z.; Du, X.; Chen, K.; Xin, X.; Jin, Z.; Shen, J.; Hu, Y.; Li, G.; et al. Effects of the natural flavone trimethylapigenin on cardiac potassium currents. Biochem. Pharmacol. 2012, 84, 498-506. [CrossRef] [PubMed]

74. Yang, L.; Ma, J.; Zhang, P.; Zou, A.; Tu, D. Quercetin activates human Kv1.5 channels by a residue I502 in the S6 segment. Clin. Exp. Pharmacol. Physiol. 2009, 36, 154-161. [CrossRef] [PubMed]

75. Wu, H.-J.; Wu, W.; Sun, H.-Y.; Qin, G.-W.; Wang, H.-B.; Wang, P.; Yalamanchili, H.K.; Wang, J.; Tse, H.-F.; Lau, C.-P.; et al. Acacetin causes a frequency- and use-dependent blockade of hKv1.5 channels by binding to the S6 domain. J. Mol. Cell. Cardiol. 2011, 51, 966-973. [CrossRef] [PubMed]

76. Paffett, M.L.; Lucas, S.N.; Campen, M.J. Resveratrol reverses monocrotaline-induced pulmonary vascular and cardiac dysfunction: A potential role for atrogin-1 in smooth muscle. Vasc. Pharmacol. 2012, 56, 64-73. [CrossRef]

77. Kwak, Y.G.; Choi, B.-H.; Kim, D.K.; Eun, J.S. Decursin from Angelica gigas Nakai blocks $h$ Kv1.5 channel. Biomol. Ther. 2011, 19, 33-37. [CrossRef]

78. Karczewski, J.; Kiss, L.; Kane, S.A.; Koblan, K.S.; Lynch, R.J.; Spencer, R.H. High-throughput analysis of drug binding interactions for the human cardiac channel, Kv1.5. Biochem. Pharmacol. 2009, 77, 177-185. [CrossRef]

79. Yang, Q.; Lv, Q.; Feng, M.; Liu, M.; Feng, Y.; Lin, S.; Yang, J.; Hu, J. Taurine prevents the electrical remodeling in ach- $\mathrm{CaCl}_{2}$ induced atrial fibrillation in rats. In Taurine 10; Lee, D.H., Schaffer, S.W., Park, W., Kim, H.W., Eds.; Springer: Dordrecht, The Netherlands, 2017; Volume 975, pp. 821-830.

80. Peukert, S.; Brendel, J.; Pirard, B.; Bruggemann, A.; Below, P.; Kleemann, H.W.; Hemmerle, H.; Schmidt, W. Identification, synthesis, and activity of novel blockers of the voltage-gated potassium channel Kv1.5. J. Med. Chem. 2003, 46, 486-498. [CrossRef]

81. Peukert, S.; Brendel, J.; Pirard, B.; Strubing, C.; Kleemann, H.W.; Bohme, T.; Hemmerle, H. Pharmacophore-based search, synthesis, and biological evaluation of anthranilic amides as novel blockers of the Kv1.5 channel. Bioorg. Med. Chem. Lett. 2004, 14, 2823-2827. [CrossRef]

82. Schmitz, A.; Sankaranarayanan, A.; Azam, P.; Schmidt-Lassen, K.; Homerick, D.; Hansel, W.; Wulff, H. Design of PAP-1, a selective small molecule Kv1.3 blocker, for the suppression of effector memory T cells in autoimmune diseases. Mol. Pharmacol. 2005, 68, 1254-1270. [CrossRef]

83. Blass, B.E.; Coburn, K.; Lee, W.; Fairweather, N.; Fluxe, A.; Wu, S.; Janusz, J.M.; Murawsky, M.; Fadayel, G.M.; Fang, B.; et al. Synthesis and evaluation of (2-phenethyl-2H-1,2,3-triazol-4-yl)(phenyl) methanones as Kv1.5 channel blockers for the treatment of atrial fibrillation. Bioorg. Med. Chem. Lett. 2006, 16, 4629-4632. [CrossRef] [PubMed]

84. Fluxe, A.; Wu, S.D.; Sheffer, J.B.; Janusz, J.M.; Murawsky, M.; Fadayel, G.M.; Fang, B.; Hare, M.; Djandjighian, L. Discovery and synthesis of tetrahydroindolone-derived carbamates as Kv1.5 blockers. Bioorg. Med. Chem. Lett. 2006, 16, 5855-5858. [CrossRef] [PubMed] 
85. Wu, S.; Fluxe, A.; Janusz, J.M.; Sheffer, J.B.; Browning, G.; Blass, B.; Cobum, K.; Hedges, R.; Murawsky, M.; Fang, B.; et al. Discovery and synthesis of tetrahydroindolone derived semicarbazones as selective Kv1.5 blockers. Bioorg. Med. Chem. Lett. 2006, 16, 5859-5863. [CrossRef] [PubMed]

86. Nanda, K.K.; Nolt, M.B.; Cato, M.J.; Kane, S.A.; Kiss, L.; Spencer, R.H.; Wang, J.; Lynch, J.J.; Regan, C.P.; Stump, G.L.; et al. Potent antagonists of the Kv1.5 potassium channel: Synthesis and evaluation of analogous N,N-diisopropyl-2-(pyridine-3-yl)acetamides. Bioorg. Med. Chem. Lett. 2006, 16, 5897-5901. [CrossRef]

87. Trotter, B.W.; Nanda, K.K.; Kett, N.R.; Regan, C.P.; Lynch, J.J.; Stump, G.L.; Kiss, L.; Wang, J.; Spencer, R.H.; Kane, S.A.; et al. Design and synthesis of novel isoquinoline-3-nitriles as orally bioavailable Kv1.5 antagonists for the treatment of atrial fibrillation. J. Med. Chem. 2006, 49, 6954-6957. [CrossRef]

88. Eun, J.S.; Kim, K.S.; Kim, H.N.; Park, S.A.; Ma, T.-Z.; Lee, K.A.; Kim, D.K.; Kim, H.K.; Kim, I.S.; Jung, Y.H.; et al. Synthesis of psoralen derivatives and their blocking effect of $h \mathrm{Kv} 1.5$ channel. Arch. Pharmacol. Res. 2007, 30, 155-160. [CrossRef] [PubMed]

89. Jackson, C.M.; Blass, B.; Coburn, K.; Djandjighian, L.; Fadayel, G.; Fluxe, A.J.; Hodson, S.J.; Janusz, J.M.; Murawsky, M.; Ridgeway, J.M.; et al. Evolution of thiazolidine-based blockers of human Kv1.5 for the treatment of atrial arrhythmias. Bioorg. Med. Chem. Lett. 2007, 17, 282-284. [CrossRef] [PubMed]

90. Lloyd, J.; Atwal, K.S.; Finlay, H.J.; Nyman, M.; Huynh, T.; Bhandaru, R.; Kover, A.; Schmidt, J.; Vaccaro, W.; Conder, M.L.; et al. Benzopyran sulfonamides as K(v)1.5 potassium channel blockers. Bioorg. Med. Chem. Lett. 2007, 17, 3271-3275. [CrossRef] [PubMed]

91. Finlay, H.J.; Lloyd, J.; Nyman, M.; Conder, M.L.; West, T.; Levesque, P.; Atwal, K. Pyrano- [2,3b] -pyridines as potassium channel antagonists. Bioorg. Med. Chem. Lett. 2008, 18, 2714-2718. [CrossRef]

92. Gross, M.F.; Castle, N.A.; Zou, A.; Wickenden, A.D.; Yu, W.; Spear, K.L. Aryl sulfonamido tetralin inhibitors of the Kv1.5 ion channel. Bioorg. Med. Chem. Lett. 2009, 19, 3063-3066. [CrossRef]

93. Blass, B.E.; Fensome, A.; Trybulski, E.; Magolda, R.; Gardell, S.J.; Liu, K.; Samuel, M.; Feingold, I.; Huselton, C.; Jackson, C.M.; et al. Selective Kv1.5 blockers: Development of $(R)-1$-(methylsulfonylamino)-3-2-(4-methoxyphenyl)ethyl -4-(4-methoxyphe nyl)-2-imidazolidinone (KVI-020/WYE-160020) as a potential treatment for atrial arrhythmia. J. Med. Chem. 2009, 52, 6531-6534. [CrossRef]

94. Blass, B. Derivatives of heteroarylsulfonamides, their peparation, and their application in human therapy patent highlight. Acs Med. Chem. Lett. 2012, 3, 618-619. [CrossRef]

95. Finlay, H.J.; Lloyd, J.; Vaccaro, W.; Kover, A.; Yan, L.; Bhave, G.; Prol, J.; Tram, H.; Bhandaru, R.; Caringal, Y.; et al. Discovery of ((S)-5-(methoxymethyl)-7-(1-methyl-1H-indol-2-yl)-2-(trifluoromethyl)-4, 7-dihydropyrazolo 1,5-a pyrimidin-6-yl)((S)-2-(3-methylisoxazol-5-yl)pyr rolidin-1-yl)methanone as a potent and selective I-Kur inhibitor. J. Med. Chem. 2012, 55, 3036-3048. [CrossRef] [PubMed]

96. Finlay, H.J.; Jiang, J.; Caringal, Y.; Kover, A.; Conder, M.L.; Xing, D.; Levesque, P.; Harper, T.; Hsueh, M.M.; Atwal, K.; et al. Triazolo and imidazo dihydropyrazolopyrimidine potassium channel antagonists. Bioorg. Med. Chem. Lett. 2013, 23, 1743-1747. [CrossRef] [PubMed]

97. Guo, X.; Yang, Q.; Xu, J.; Zhang, L.; Chu, H.; Yu, P.; Zhu, Y.; Wei, J.; Chen, W.; Zhang, Y.; et al. Design and bio-evaluation of indole derivatives as potent Kv1.5 inhibitors. Bioorg. Med. Chem. 2013, 21, 6466-6476. [CrossRef]

98. Olsson, R.I.; Jacobson, I.; Bostrom, J.; Fex, T.; Bjore, A.; Olsson, C.; Sundell, J.; Gran, U.; Ohrn, A.; Nordin, A.; et al. Synthesis and evaluation of diphenylphosphinic amides and diphenylphosphine oxides as inhibitors of Kv1.5. Bioorg. Med. Chem. Lett. 2013, 23, 706-710. [CrossRef] [PubMed]

99. Olsson, R.I.; Jacobson, I.; Iliefski, T.; Bostrom, J.; Davidsson, O.; Fjellstrom, O.; Bjore, A.; Olsson, C.; Sundell, J.; Gran, U.; et al. Lactam sulfonamides as potent inhibitors of the Kv1.5 potassium ion channel. Bioorg. Med. Chem. Lett. 2014, 24, 1269-1273. [CrossRef]

100. Johnson, J.A.; Xu, N.; Jeon, Y.; Finlay, H.J.; Kover, A.; Conder, M.L.; Sun, H.; Li, D.; Levesque, P.; Hsueh, M.-M.; et al. Design, synthesis and evaluation of phenethylaminoheterocycles as $\mathrm{K}(\mathrm{v}) 1.5$ inhibitors. Bioorg. Med. Chem. Lett. 2014, 24, 3018-3022. [CrossRef]

101. Guo, X.; Ma, X.; Yang, Q.; Xu, J.; Huang, L.; Jia, J.; Shan, J.; Liu, L.; Chen, W.; Chu, H.; et al. Discovery of 1-aryloxyethyl piperazine derivatives as Kv1.5 potassium channel inhibitors (part I). Eur. J. Med. Chem. 2014, 81, 89-94. [CrossRef] 
102. Kajanus, J.; Jacobson, I.; Astrand, A.; Olsson, R.I.; Gran, U.; Bjore, A.; Fjellstrom, O.; Davidsson, O.; Emtenas, H.; Dahlen, A.; et al. Isoindolinone compounds active as Kv1.5 blockers identified using a multicomponent reaction approach. Bioorg. Med. Chem. Lett. 2016, 26, 2023-2029. [CrossRef] [PubMed]

103. Finlay, H.J.; Johnson, J.A.; Lloyd, J.L.; Jiang, J.; Neels, J.; Gunaga, P.; Baneriee, A.; Dhondi, N.; Chimalakonda, A.; Mandlekar, S.; et al. Discovery of 5-Phenyl-N-(pyridin-2-ylmethyl)-2-(pyrimidin-5-yl)quinazolin-4-amine as a Potent I-Kur Inhibitor. Acs Med. Chem. Lett. 2016, 7, 831-834. [CrossRef] [PubMed]

104. Zidar, N.; Zula, A.; Tomasic, T.; Rogers, M.; Kirby, R.W.; Tytgat, J.; Peigneur, S.; Kikelj, D.; Ilas, J.; Masic, L.P. Clathrodin, hymenidin and oroidin, and their synthetic analogues as inhibitors of the voltage-gated potassium channels. Eur. J. Med. Chem. 2017, 139, 232-241. [CrossRef] [PubMed]

105. Wolkenberg, S.E.; Nolt, M.B.; Bilodeau, M.T.; Trotter, B.W.; Manley, P.J.; Kett, N.R.; Nanda, K.K.; Wu, Z.C.; Cato, M.J.; Kane, S.A.; et al. Discovery of MK-1832, a Kv1.5 inhibitor with improved selectivity and pharmacokinetics. Bioorg. Med. Chem. Lett. 2017, 27, 1062-1069. [CrossRef] [PubMed]

106. Kajanus, J.; Antonsson, T.; Carlsson, L.; Jurva, U.; Pettersen, A.; Sundell, J.; Inghardt, T. Potassium channel blocking 1,2-bis(aryl)ethane-1,2-diamines active as antiarrhythmic agents. Bioorg. Med. Chem. Lett. 2019, 29, 1241-1245. [CrossRef]

107. Banerjee, S.; Adhikari, N.; Amin, S.A.; Jha, T. Histone deacetylase 8 (HDAC8) and its inhibitors with selectivity to other isoforms: An overview. Eur. J. Med. Chem. 2019, 164, 214-240. [CrossRef] [PubMed]

108. Zhao, Z.; Song, H.; Xie, J.; Liu, T.; Zhao, X.; Chen, X.; He, X.; Wu, S.; Zhang, Y.; Zheng, X. Research progress in the biological activities of 3,4,5-trimethoxycinnamic acid (TMCA) derivatives. Eur. J. Med. Chem. 2019, 173, 213-227. [CrossRef]

(C) 2019 by the authors. Licensee MDPI, Basel, Switzerland. This article is an open access article distributed under the terms and conditions of the Creative Commons Attribution (CC BY) license (http://creativecommons.org/licenses/by/4.0/). 